\title{
Entrepreneurship, Economic Conditions, and the Great Recession
}

\author{
Robert W. Fairlie \\ Department of Economics \\ University of California \\ Santa Cruz, CA 95064 \\ rfairlie@ucsc.edu \\ IZA and RAND
}

May 2011

\begin{abstract}
The "Great Recession" resulted in many business closings and foreclosures, but what effect did it have on business formation? On the one hand, recessions decrease potential business income and wealth, but on the other hand they restrict opportunities in the wage/salary sector leaving the net effect on entrepreneurship ambiguous. The most up-to-date microdata available -- the 1996 to 2009 Current Population Survey (CPS) -- are used to conduct a detailed analysis of the determinants of entrepreneurship at the individual level to shed light on this question. Regression estimates indicate that local labor market conditions are a major determinant of entrepreneurship. Higher local unemployment rates are found to increase the probability that individuals start businesses. Home ownership and local home values for home owners are also found to have positive effects on business creation, but these effects are noticeably smaller. Additional regression estimates indicate that individuals who are initially not employed respond more to high local unemployment rates by starting businesses than wage/salary workers. The results point to a consistent picture - the positive influences of slack labor markets outweigh the negative influences resulting in higher levels of business creation. Using the regression estimates for the local unemployment rate effects, I find that the predicted trend in entrepreneurship rates tracks the actual upward trend in entrepreneurship extremely well in the Great Recession.
\end{abstract}

Keywords: Entrepreneurship, Great Recession, Unemployment, Self-Employment JEL Code: L26

This research was supported by the Kauffman-RAND Institute for Entrepreneurship Public Policy through a grant from the Ewing Marion Kauffman Foundation. I would like to thank Susan Gates, John Robertson, Danny Leung, and seminar participants at the Small Business, Entrepreneurship, and Economic Recovery Conference at the Atlanta Federal Reserve and the CIRPEE-IVEY Conference on Macroeconomics and Entrepreneurship for helpful comments and suggestions. 


\section{Introduction}

The U.S. Economy lost more than 8 million jobs during the recession starting in December 2007. The national unemployment rate rose to over 10 percent, which is twice as high as it was at the start of the recession. Many researchers have noted that the labor market experienced its deepest downturn in the postwar era in the recent recession (Elsby, Hobijn and Sahin 2010). Sparking the recession was the housing crisis -- housing prices plummeted since reaching their peak in mid 2007. The national housing price index experienced the largest decline on record (Federal Housing Finance Agency 2009). Home foreclosures also rose rapidly over the past few years. In the one period for May 2010, there were 323,000 foreclosure filings, representing an alarming 1 out every 400 housing units in the United States (Realtytrac 2010).

What effect did the recent recession, and recessions more generally, have on entrepreneurship? Were would-be-entrepreneurs dissuaded by the recent recession from starting businesses or did they respond to layoffs and slack labor markets by turning to self-employed business ownership? Business bankruptcy filings and closures increased sharply in the recent recession (U.S. Courts 2010), but the effects on business formation are less clear. Recessions might have a negative effect on business starts because of the resulting decline in demand for the products and services produced by businesses. The recent housing slump may have limited entrepreneurship by restricting access to capital. Equity in one's home is the main asset for most Americans and represents 60 percent of all wealth (U.S. Census 2008). Home equity and other forms of personal wealth are important for starting businesses because they can be invested directly in the business or used as collateral to obtain business loans. Bank loans, venture capital and angel investments were also difficult to obtain during the recent recession (Federal Reserve Board of Governors 2010, PricewaterhouseCoopers 2010).

On the other hand, the recent recession might have increased "necessity" entrepreneurship or business creation because of the rapid rise in the number of layoffs and unemployment in the United States. Previous studies provide evidence that job loss and reduced 
labor market opportunities lead to entry into self-employed business ownership (Farber 1999; Parker 2009; Krashinsky 2005). Although the motivation might differ for starting the business in this case, many of these businesses may eventually be very successful. For example, a recent study by Stangler (2009) finds that the majority of Fortune 500 companies were started during recessions or bear markets.

Given these opposing forces, the net effect of the recent recession on business creations is ambiguous. Indeed, the positive and negative influences may have even cancelled out resulting in a relatively flat rate of business creation over the business cycle. To explore this question, I first conduct a detailed analysis of the determinants of entrepreneurship using newly created panel data from the most up-to-date microdata available -- the 1996 to 2009 Current Population Survey (CPS). Although the CPS data are usually used as cross-sectional data, panel data can be created from the underlying data files allowing one to measure business creation by individuals. Using these data, the effects of rising unemployment rates and the decline in housing values on entrepreneurship are examined by estimating the relationship between business creation at the individual level and local labor and housing markets. The analysis covers two recessions and two strong growth periods, and uses variation in unemployment and housing prices from more than 250 metropolitan areas. Estimates from this analysis are then used to examine whether rapidly increasing unemployment rates and a declining housing market had a large effect on business creation in the Great Recession.

This study is the first to provide a detailed analysis of the effects of the Great Recession on business creation in the United States. It also improves on previous research on business formation by capturing a broader range of new business activity than commonly-used Census data focusing only on new employer firms. Detailed information on home ownership, initial employment status, education and demographic characteristics of entrepreneurs and nonentrepreneurs available in the CPS allow for a much more extensive analysis of the relationship between local economic conditions, housing market conditions, and business formation than 
previously conducted in the literature. The study provides new evidence on the potentially opposing influences of unemployment and housing markets on entrepreneurship, interactions between initial employment status and local labor market conditions, and the types of business created in weak labor market conditions. The findings from this analysis may have important policy implications because of the focus of many government programs on promoting business ownership among the unemployed and the potential for job creation (U.S. Department of Labor 2010, Small Business Administration 2010, OECD 1992, 2005).

\section{The Entrepreneurial Decision}

Theoretical models of the choice to become self-employed are generally based on a comparison of potential earnings from business ownership and wage and salary work. In the classic economic model by Evans and Jovanovic (1989) individuals can obtain the following income, $\mathrm{Y}^{\mathrm{W}}$, from the wage and salary sector: $\mathrm{Y}^{\mathrm{W}}=\mathrm{w}+\mathrm{rA}$, where $\mathrm{w}$ is the wage earned in the market, $\mathrm{r}$ is the interest rate, and A represents the consumer's assets. Earnings in the selfemployment sector, $\mathrm{Y}^{\mathrm{SE}}$, are defined as: $\mathrm{Y}^{\mathrm{SE}}=\theta \mathrm{f}(\mathrm{k}) \varepsilon+\mathrm{r}(\mathrm{A}-\mathrm{k})$, where $\theta$ is entrepreneurial ability, $\mathrm{f}($.$) is a production function whose only input is capital, \varepsilon$ is a random component to the production process, and $\mathrm{k}$ is the amount of capital purchased by the worker. Individuals choose to become self-employed if the potential income from self-employment and investing remaining personal wealth after using it for startup capital is higher than the potential income from wage and salary work and investing personal wealth.

This simple theoretical model is useful for illustrating the main avenues through which business cycles might affect entrepreneurship. One of the main effects is that recessions reduce consumer and firm demand for products and services provided by startups, thus decreasing potential entrepreneurial earnings, $\mathrm{Y}^{\mathrm{SE}}$. Recessions may also reduce total wealth, A, which in turn would lower the likelihood of entrepreneurship. In the presence of liquidity constraints, lower levels of wealth may make it more difficult for entrepreneurs to find the required startup 
capital to launch new ventures. Personal wealth may have declined substantially through declining home values and home ownership rates. Recessions also make it more difficult to acquire financing from banks, other financial institutions, angel investors, and venture capitalists.

On the other hand, the costs of production are lower in a recession, especially rent and labor, increasing $\mathrm{Y}^{\mathrm{SE}}$. The opportunity cost of capital, $r$, is likely to be lower in recessions also placing upward pressure on entrepreneurship. Perhaps the largest factor having a positive effect on the entrepreneurial decision is that compensation in the wage/salary sector decreases in economic contractions. The positive effect of lower wages on entrepreneurship may be tempered somewhat in recessions, however, because some workers may be reluctant to leave their jobs in a recession because of concerns about finding another one if the business fails. The net effect of these opposing forces on entrepreneurship is ambiguous. An empirical analysis is thus needed.

\section{PREVIOUS EMPIRICAL EVIDENCE}

The previous empirical literature provides evidence on several aspects of how recessions affect the entrepreneurial decision. The relationship between personal wealth and business starts has been studied extensively in the previous literature using various methodologies, measures of wealth, and datasets from around the world. Most studies find that asset levels (e.g. net worth) measured in one year increase the probability of entering self-employment by the following year. ${ }^{1}$ The finding has generally been interpreted as providing evidence that entrepreneurs face liquidity constraints and that owner's wealth is important in determining access to financial capital for business starts. Additional evidence on the link between startup capital and owner's wealth has been provided by examining the relationship between business loans and personal commitments, such as using personal assets for collateral for business liabilities and guarantees that make

\footnotetext{
${ }^{1}$ See Evans and Jovanovic (1989), Evans and Leighton (1989), Meyer (1990), Holtz-Eakin, Joulfaian, and Rosen (1994), Lindh and Ohlsson (1996, 1998), Bates (1997), Blanchflower and Oswald (1998), Dunn and Holtz-Eakin (2000), Fairlie (1999), Johansson (2000), Taylor (2001), Zissimopoulos and Karoly (2003), Holtz-Eakin and Rosen (2005), Giannetti and Simonov (2004), Fairlie and Krashinsky (2010), and Nykvist (2005).
} 
owners personally liable for business debts (Avery, Bostic and Samolyk 1998, Cavalluzzo and Wolken 2005). Additional evidence on the importance of wealth is provided by the finding that the substantial racial disparities in wealth found in the United States contribute greatly to why blacks and Latinos have low business creation rates and worse business outcomes and why Asian businesses are relatively successful (Bates 1997, Fairlie 1999, Fairlie and Woodruff 2010, Fairlie and Robb 2007, 2008, Lofstrom and Wang 2009, Bates and Lofstrom 2008).

A smaller literature has examined the relationship between home ownership and entrepreneurship. The lack of research is surprising because the single largest asset held by most households is their home. Estimates of home ownership indicate that 67.2 percent of Americans own their own home with a median home equity of $\$ 59,000$ (U.S. Census Bureau 2008). The majority of Americans thus have equity in their homes that may be tapped into for capital to start businesses or expand a small business. Home ownership and equity are found to be associated with entrepreneurship and obtaining business loans using Finish data (Johansson 2000), U.K. data (Black, de Meza, and Jeffreys 1996), and data from the U.S. Survey of Small Business Finances (Cavalluzzo and Wolken 2005). A comprehensive study of home ownership and business formation at the individual level, however, has not been conducted in the previous literature. One area in particular that remains understudied is whether home ownership is important for entrepreneurship even after controlling for detailed information on education and other demographic information. Carefully controlling for the effects of education on entrepreneurship may be especially important because education and wealth are highly correlated and education has a large positive effect on entrepreneurship and business performance. ${ }^{2}$

Previous research on the relationship between unemployment and entrepreneurship provides mixed results. Parker (2009) reviews the literature and cites many previous studies showing positive relationships, negative relationships, and zero relationships. He notes, however,

\footnotetext{
${ }^{2}$ See van der Sluis, van Praag and Vijverberg (2005), van Praag (2005), and Moutray (2007) for reviews of the evidence on the relationship between education and entrepreneurship.
} 
that more recent studies are generally finding evidence of a positive or zero relationship between unemployment and entrepreneurship. A recent paper by Stangler and Kedrosky (2010) using several data sources finds of a roughly constant rate of firm formation over time. Their analysis of published aggregate data on employer firm births from the U.S. Census Bureau over the period from 1977 to 2005 does not indicate a strong cyclical pattern in business formation rates. These data, however, do not include the time period covered by the Great Recession.

This study builds on the findings of the previous literature by examining the relationship between entrepreneurship and both conditions in local labor markets and local housing markets. It is the first study to use data from the Great Recession to estimate this relationship and directly examine the effects of the Great Recession on business creation. It also provides new evidence on whether initial employment conditions interact with local labor market conditions in determining business creation, and the types of businesses created in slack labor market conditions.

\section{Data}

Although research on entrepreneurship is growing rapidly, there are very few national datasets that provide information on the determinants of entrepreneurship. Using matched data from the 1996-2009 Current Population Surveys (CPS), I use a recently created measure of entrepreneurship, which captures the rate of business creation at the individual owner level. National and state-level estimates are reported in Fairlie (2010). The underlying datasets that are used to create the entrepreneurship measure are the basic monthly files to the Current Population Survey (CPS). Longitudinal data is created by linking the CPS files over time. These surveys, conducted monthly by the U.S. Bureau of the Census and the U.S. Bureau of Labor Statistics, are representative of the entire U.S. population and contain observations for more than 130,000 people. Combining the 1996 to 2009 monthly data creates a sample size of more than 10 million adult observations. CPS sample weights are used in all analyses. 
Households in the CPS are interviewed each month over a 4-month period. Eight months later they are re-interviewed in each month of a second 4-month period. Thus, individuals who are interviewed in January, February, March and April of one year are interviewed again in January, February, March and April of the following year. The rotation pattern of the CPS, thus allows for matching information on individuals monthly for 75 percent of all respondents to each survey because the four month in the rotation cannot be matched to a subsequent month. To match these data, I use the household and individual identifiers provided by the CPS. False matches are removed by comparing race, sex and age codes from the two months. All nonunique matches are also removed from the dataset. Finally, the datasets provided by the BLS are checked extensively for coding errors and other problems. Monthly match rates are generally between 94 and 96 percent, and false positive rates are very low. ${ }^{3}$

\section{MEASURING ENTREPRENEURSHIP}

Measures of the number and rate of business ownership are available from several large, nationally representative government datasets, such as the Survey of Business Owners (SBO), Census PUMS files, and the American Community Survey (ACS). Measures of business ownership based on these cross-sectional data, however, cannot capture the dynamic nature of entrepreneurship. A measure of business formation, or the rate of flow into business ownership, is needed to represent entrepreneurship. ${ }^{4}$ Using the matched CPS data over time, I create a measure of business formation that captures all new business owners including those who own incorporated or unincorporated businesses, and those who are employers or non-employers.

\footnotetext{
${ }^{3}$ The main reason for non-matching is when someone moves. Therefore, a somewhat non-random sample (mainly geographic movers) will be lost due to the matching routine. For these month-to-month matches this does not appear to create a serious problem, however, because the observable characteristics of the original sample and the matched sample are very similar. See Fairlie (2010) for more details on matching. ${ }^{4}$ The Total Entrepreneurial Activity (TEA) index used in the Global Entrepreneurship Monitor captures individuals who are involved in either the startup phase or managing a business that is less than 42 months old (Reynolds, Bygrave and Autio 2003).
} 
Two of the only other large, nationally representative datasets that provide a measure of business formation are the Statistics for U.S. Businesses (SUSB) and Business Employment Dynamics (BED). ${ }^{5}$ The CPS data, however, provide for a much broader range of new business activity than these datasets because the SUSB and BED are limited to measuring only births for employer establishments or firms. The exclusion of non-employer firms is likely to lead to a substantial undercount of the rate of entrepreneurship because non-employer firms represent 75 percent of all firms (U.S. Small Business Administration 2001, Headd 2005) and a significant number of new employer firms start as non-employer firms (Davis, et. al. 2006).

To estimate the business formation rate in the matched CPS data, I first identify all individuals who do not own a business as their main job in the initial survey month in the twomonth pair. By matching CPS files, I then identify whether they own a business as their main job with 15 or more usual hours worked in the subsequent survey month. ${ }^{6}$ The entrepreneurship rate is thus defined as the percentage of the population of non-business owners that start a business each month. To identify whether they are business owners in each month I use information on their main job defined as the one with the most hours worked. Thus, individuals who start side businesses will not be counted if they are working more hours on a wage and salary job. The 15 or more hours per week (or roughly 2 or more days per week) criterion is chosen to guarantee a reasonable work commitment to the new business.

In addition to being able to carefully define entrepreneurship, the CPS data include information on home ownership and detailed demographic information including race, gender, age, education and family income at the individual level. Large-scale, nationally representative

\footnotetext{
${ }^{5}$ The SUSB is conducted by the U.S. Census Bureau and reported by the U.S. Small Business Administration, Office of Advocacy, and the Business Employment Dynamics (BED) is conducted by the U.S. Bureau of Labor Statistics.

${ }^{6}$ All observations with allocated labor force status, class of worker, and hours worked variables are excluded from the sample. Missing values for variables in the CPS are allocated or imputed by using several procedures including hot deck procedures and information from previous survey months. These allocation procedures lead to higher estimated entrepreneurship rates because allocations are likely to increase the likelihood of changes (see Fairlie 2010 for more details).
} 
business-level data include only very limited or no information on the business owner.

Furthermore, microdata from the most comprehensive of these business-level datasets, such as the SUSB and BED, are confidential and restricted-access. To examine the relationship between entrepreneurship, and unemployment and housing, I append local unemployment rates and housing prices to the individual-level data. Local labor and housing markets are defined by metropolitan areas. The CPS identifies more than 250 metropolitan areas in the United States.

In sum, the matched CPS is the only dataset that provides the six criteria needed for this study. It provides a measure of business formation (i.e. panel data), long time period, large sample size, geographical identifiers, detailed owner's characteristics, and covers the Great Recession.

\section{The Great Recession and Entrepreneurship}

As a first pass at examining recessionary effects on entrepreneurship, I present national trends in unemployment, home ownership, home values and entrepreneurship. Figure 1 displays the national unemployment rate since the beginning of 1996. I focus on the period starting in 1996 because it captures the start of the strong economic growth period of the 1990s reasonably well and because of data limitations in matching the CPS in immediately preceding years. ${ }^{7}$ The period from the beginning of 1996 to the end of 2009 captures two downturns and two growth periods. The NBER officially dates the peak of the strong economic growth period of the late 1990s as March 2001 and the subsequent contraction period as ending in November 2001. The next peak of the business cycle was December 2007 and the official end of the recent recession

\footnotetext{
${ }^{7}$ The NBER dates the trough of the early 1990s business cycle as occurring in March 1991, but an examination of the national unemployment rate reveals that unemployment reached its peak in mid 1992 and real GDP growth was not consistently high until the third quarter of 1995 (it was very low in the first two quarters of 1995). It is not possible to extend the sample period backwards a couple years because it is not possible to create entrepreneurship data for 1994 and 1995. In these years, the Bureau of Labor Statistics re-randomized the identification codes making it impossible to match individuals over time. However, 1996 is the first year in which the unemployment rate was consistently declining and real GDP growth was consistently high.
} 
was June 2009, although unemployment remained very high throughout 2009 (NBER 2010, U.S. Bureau of Labor Statistics 2010). The national unemployment rate was steadily decreasing in the late 1990s and even fell below 4 percent in late 2000. As the U.S. economy then slipped into a recession the unemployment rate increased steadily and rose above 6 percent in the middle of 2003. The macroeconomic recovery that started in November 2001 helped to reduce the unemployment rate to a low of roughly 4.5 percent in mid 2007. After this low point, unemployment rose relatively slowly until the second quarter of 2008 when it rose very quickly. Remarkably, in one year it rose nearly 4 percentage points. Within only a half year later it rose another full percentage point ending up above 10 percent in October 2009. This increase in unemployment represents the deepest downturn that the labor market has experienced in the postwar era and has been dubbed, the "Great Recession."

In addition to rising unemployment, over the past couple of years housing values have dropped precipitously. Figure 2 displays the median sales price of existing single-family homes from the National Association of Realtors. In the second quarter of 2007 the median house price was $\$ 223,500$. By the fourth quarter of 2009 median house prices dropped to $\$ 172,100 .^{8}$ In constant 2009 dollars, the drop in home prices was even larger. The median home price adjusted for inflation dropped from $\$ 234,469$ in 2007 Q2 to $\$ 172,100$ in 2009 Q4, representing a decline of 27 percent. Before the housing crisis home prices increased steadily. Although the increase is somewhat tempered by inflation, in both real and nominal terms housing prices rose in the late 1990s and early 2000s, were constant for a couple of years, and dropped rapidly after the summer of 2007.

Figure 2 also displays home ownership rates from 1996 to 2009. Home ownership rates rose in the late 1990s and early 2000s, but declined starting in 2007. In the Great Recession, many individuals were forced to either sell or foreclose on their homes because they could not

\footnotetext{
${ }^{8}$ The housing market decline affected all parts of the country. Examining changes in metropolitan area prices over the same period of time, only a handful of areas did not experience declining prices.
} 
make their housing payments, which negatively impacted national home ownership rates (Realtytrac 2010). These changes in home ownership rates, however, are much less severe than the changes in housing prices.

\section{TRENDS IN ENTREPRENEURSHIP}

How has entrepreneurship fared over the same period of time in which unemployment rates have increased rapidly and the housing market has dropped significantly? Figure 3 displays annual estimates of the monthly entrepreneurship rate from 1996 to 2009. As noted above the entrepreneurship rate measures the percentage of the adult, non-business owner population that starts a business each month. It captures all new business owners, including those who own incorporated or unincorporated business, and those who are employers or non-employers. In 2009 , an average of 0.34 percent of the adult population, or 340 out of 100,000 adults created a new business each month. The business formation rate increased from 2008 when it was 0.32 percent. It was the third straight year that the index increased, resulting in an increase from 0.29 percent in 2006 to 0.34 percent in 2009. The recent increase is the largest over the fourteen-year sample period. In fact, over the period from 1996 to 2009, the business creation rate fluctuated within the range of 0.27 percent to 0.31 percent. It was not until 2008 and 2009 that it rose above the high end of this range, which coincides with the recent recession. In the late 1990s, the entrepreneurship rate decreased slightly, then rose from 2001 to 2003. It remained relative constant over the next three years before increasing in the recent recession.

As displayed above, unemployment rates followed a clear cyclical pattern over the past decade and a half. To examine the relationship between unemployment and entrepreneurship, Figure 3 plots an annualized measure of the unemployment rate in addition to the entrepreneurship rate. The entrepreneurship rate follows the same cyclical pattern as the unemployment rate. Both entrepreneurship and unemployment were high in 1996 then declined steadily in the strong economic growth period of the late 1990s. Both rates increased in the early 
2000 s corresponding with the recession. In the mid 2000s both rates declined until the start of the current recession in 2007 . The unemployment rate rose very rapidly over the next two years. The entrepreneurship rate also rose in these two years.

The national entrepreneurship and unemployment rates followed the same time-series pattern over the period from 1996 to 2009 . The relationship between the two measures appears to be very strong. But, the displayed patterns are somewhat deceptive. The cyclical pattern in the entrepreneurship rate is much less pronounced in relative terms than for the unemployment rate. Taking the current recession as an example, the unemployment rate increased from 4.6 percent in 2006 to 9.3 percent in 2009. This represents an increase of more than 100 percent. The entrepreneurship rate increased from 0.29 percent in 2006 to 0.34 percent in 2009. This represents an increase of 17 percent. Thus, the entrepreneurship rate does not follow nearly as strong of a cyclical trend as the unemployment rate which may be due to the opposing forces noted above.

Figure 4 displays the entrepreneurship rate against the national median home price in \$2009. The negative relationship between the two trends in the recent recession is very clear. Home prices have dropped sharply over the past few years as entrepreneurship rates have increased. These patterns run counter to the decline in home equity decreasing entrepreneurship and are likely due to stronger positive effects of rising unemployment rates. Entrepreneurship rates also dropped in the late 1990s when home prices were rising. Interestingly, however, both entrepreneurship and home prices rose steadily in the early 2000s. In this period, rising home equity may have provided capital for would-be-entrepreneurs to start businesses.

At the national level, trends in entrepreneurship appear to be primarily counter cyclical -rising in economic downturns and declining in strong economic growth periods. The national patterns for entrepreneurship, however, are weaker than unemployment patterns over the business cycle. Trends in home prices and their effects on access to capital may have offset some of the business cycle effects. But, these are only broad strokes based on national trends. Instead, it is important to focus on variation in local labor market and housing conditions. Unemployment 
rates and housing prices differ substantially across metropolitan areas, and these differences can be used to more carefully examine the relationship between entrepreneurship, and unemployment and home prices.

\section{Unemployment, Home Ownership and Entrepreneurship}

I first examine the overall relationship between unemployment rates in local labor markets and entrepreneurship. Figure 5 displays the entrepreneurship rate for various levels of metropolitan area unemployment rates. These capture variation across metropolitan areas as well as over time. Entrepreneurship rates are 0.22 percent for local labor markets with an unemployment rate under 2 percent. The rate of entrepreneurship rises steadily with the unemployment rate reaching a peak of 0.34 percent for local labor markets with unemployment rates of 10 percent or higher. ${ }^{9}$ The relationship between entrepreneurship rates and local labor markets appears to be roughly linear through the displayed range of unemployment rates.

I next examine the relationship between home ownership and entrepreneurship in the CPS. Entrepreneurship rates for home owners do not differ from those for non home owners. Both rates equal 0.29 percent. Home owners are thus not more likely to start businesses than are non-home owners, but this finding could change after controlling for other characteristics of the individual, especially income and employment status. Home ownership is strongly correlated with income and employment.

Home owners differ in their levels of home equity to potentially borrow against to start businesses, partly because of geographical differences in housing prices. Focusing on home owners, Figure 6 displays entrepreneurship rates by a range of home values in the metropolitan

\footnotetext{
${ }^{9}$ The distribution of local unemployment rates is skewed to the right in the Great Recession. Unemployment rates of 7 percent or higher comprise 42 percent of the sample in the Great Recession whereas they comprise only 18 percent of the sample in non-recessionary months. Unemployment rates of 10 percent or higher comprise 16 percent of the sample in the Great Recession (5 percent in nonrecessionary months).
} 
area by quarter. ${ }^{10}$ Entrepreneurship rates steadily increase with median home prices. For home owners living in MSAs with median home prices less than $\$ 100,000$ the entrepreneurship rate is 0.26 percent. The entrepreneurship rate increases to 0.33 percent for individuals living in MSAs with median home prices of $\$ 500,000$ or more. The relationship appears to be roughly linear.

The relationships between entrepreneurship and local unemployment rates, home ownership, and local home prices appear to be stronger than the relationship indicated by the national trends in these measures. A more detailed analysis, especially one that controls for the potentially opposing forces of rising local unemployment rates and declining home values in recessions, is needed.

\section{REGRESSION ANALYSIS}

To examine the independent effects of local labor market unemployment rates and housing markets, I turn to a regression analysis. The following regression equation for the probability of entrepreneurship is estimated:

(5.1) $\mathrm{y}_{\mathrm{imt}}=\alpha+\gamma_{1} \mathrm{U}_{\mathrm{mt}}+\gamma_{2} \mathrm{H}_{\mathrm{imt}}+\beta^{\prime} \mathrm{X}_{\mathrm{imt}}+\lambda_{\mathrm{t}}+\varepsilon_{\mathrm{imt}}$,

where $y_{\text {imt }}$ equals 1 if the individual starts a business by the second or subsequent survey month in the two-month pair and 0 otherwise, $\mathrm{U}_{\mathrm{mt}}$ is the unemployment rate in the local labor market (metropolitan area) in month $\mathrm{t}, \mathrm{H}_{\mathrm{imt}}$ is whether the individual owns his or her home, $\mathrm{X}_{\mathrm{imt}}$ includes individual characteristics, $\lambda_{t}$ are month fixed effects to control for seasonal variation, and $\varepsilon_{\text {imt }}$ is the error term. The individual characteristics include gender, race/ethnicity, nativity, age, education, family income, marital status, region, and urban status. The parameters of interest are $\gamma_{1}$ and $\gamma_{2} \cdot \gamma_{1}$ captures the effects of local labor market conditions on entrepreneurship, and $\gamma_{2}$ captures the relationship between whether an individual owns a home and entrepreneurship. In some specifications, I replace home ownership with a proxy for home equity based on local home

\footnotetext{
${ }^{10}$ MSA median home prices are measured quarterly and were obtained by special request to the National Association of Realtors.
} 
prices (defined by the metropolitan area). All specifications are estimated with OLS using CPS sample weights, and robust standard errors are reported with adjustments for multiple observations per MSA/month (i.e. clustered by MSA/month). Marginal effects estimates are similar from probit and logit models, and are thus not reported.

Table 1 reports estimates of (5.1). The base specification includes controls for individual characteristics. The estimates indicate that women are less likely to become entrepreneurs. African-Americans, Latinos, and Asians are also less likely to start businesses, all else equal. ${ }^{11}$ Immigrants, however, are more likely than the native-born to start businesses. Immigrants have entrepreneurship rates that are 0.12 percentage points higher than U.S. born rates.

Entrepreneurship increases with age and married people are more likely to start businesses.

The relationship between entrepreneurship and education is not linear. Entrepreneurship rates are lower for high school graduates than for high school dropouts (the left out category), but entrepreneurship rates are similar between those with some college and high school graduates. Although college graduates and those with graduate degrees have higher rates of entrepreneurship than high school graduates they essentially have the same rate of entrepreneurship as high school dropouts. Thus, there appears to be somewhat of a U-shaped relationship between entrepreneurship and education. Entrepreneurship rates tend to decline with total family income.

Turning to the effects of local labor market conditions on entrepreneurship, Specification 1 includes the local labor market unemployment rate. The coefficient estimate is positive and statistically significant. It implies that an increase in the local unemployment rate by 5 percentage points increases entrepreneurship rates by 0.04 percentage points (or 15 percent of the mean level). ${ }^{12}$ A 5 percentage point increase in the unemployment rate is roughly the same magnitude

\footnotetext{
${ }^{11}$ These patterns are consistent with low rates of minority business ownership except for Asians who are found to have higher rates of business ownership (Fairlie and Robb 2008).

${ }^{12}$ Although the influence that less precisely measured unemployment rates in smaller MSAs can have in the regressions is small because the regression sample is implicitly weighted by MSA size, I check the sensitivity of the estimates to the inclusion of less-precisely estimated local unemployment rates. I first estimate the regression including only the largest 100 MSAs, which includes 83 percent of the original
} 
as the increase in unemployment from the start of the current recession to the end of 2009 as displayed in Figure 1.

Another interesting finding is that home owners are more likely to start businesses. The coefficient is positive and statistically significant, although relatively small. Home owners have a 0.012 percentage point higher rate of entrepreneurship than non-home owners, which is roughly a 4 percent higher rate relative to the mean. In the presence of liquidity constraints, the ability of owners to borrow against the value of their homes, such as home equity loans, may make it easier to finance new business ventures.

In Specification 2, I include industry controls. Industries differ in their propensity for individuals to start businesses and the industrial composition of metropolitan areas may be related to unemployment rates and housing prices. Construction has the highest rate of business creation followed by Professional Services. The lowest rate of entrepreneurship is found in Manufacturing. The addition of industry controls, however, has little effect on the results for the local unemployment rate. Local unemployment rates continue to have a large positive effect on entrepreneurship. The home ownership coefficient declines somewhat becoming statistically insignificant. Industry controls are not included in the main specification because of endogeneity concerns. The main issue is that the choice of industry and the choice of starting a business may be simultaneously determined. Workers are not constrained to starting businesses in their current industry and may choose different industries depending on the goals of their businesses.

To further check the robustness of the results, Specification 3 includes a smooth time trend. A quadratic time trend is included to capture any long-term, slower moving trends in entrepreneurship. Controlling for time trends is complicated by the goal of capturing the effects

regression sample. The coefficient estimate on the local unemployment rate is 0.0 .0109 which is larger, but not substantially different than the original estimate of 0.00842 . I also estimate a specification that excludes any observation in which the local unemployment rate (MSA/month) estimate was based on a sample size of less than 50 observations ( 5 percent of the sample). The coefficient estimate on the local unemployment is 0.008843 which is only slightly larger than the original estimate. Thus, there might be a downward bias in the original estimate from measurement error due to smaller MSAs, but it is does not appear to be very large. 
of the business cycle. Clearly, the inclusion of year dummies or a very flexible time trend (that allows repeated ups and downs) would not make sense in the context of estimating the effects of recessions on entrepreneurship. The inclusion of these variables would "over fit" the data and remove the possibility of identifying recessionary effects. A quadratic specification captures a smooth, longer-term trend over the period from 1996 to 2009 and does not allow the shape of a double peaked business cycle over the period. In this specification, the coefficient on the local unemployment rate becomes smaller, but remains large and statistically significant. ${ }^{13}$ The home ownership coefficient is similar to the one reported in Specification 1. Thus, the estimates are not being driven by longer term trends in entrepreneurship.

In the final specification reported in Table 1, I estimate a regression equation that includes fixed effects for every MSA identified in the CPS (264). The inclusion of these fixed effects controls for differences across MSAs that are fixed over time. Unobservable differences across MSAs such as the general political and business climate might confound the results. In this specification, identification of the effect of local unemployment rates and home ownership are identified solely by changes over time within MSAs. This specification removes the effects of the variation in long-term differences across local markets and focuses on the business cycle variation. In Specification 4, the coefficient estimate on the local unemployment rate becomes slightly larger. A 5 percentage point increase in the local unemployment rate results in a 0.058 percentage points (or 20 percent of the mean level) increase in the entrepreneurship rate. This result suggests that economic fluctuations over time are primarily identifying the strong positive relationship between entrepreneurship and local unemployment rates. The home ownership coefficient is also larger in this specification. The inclusion of MSA fixed effects increases the coefficient estimate on home ownership to 0.020 percentage points.

\footnotetext{
${ }^{13}$ Although not reported, I also estimate a specification that includes a linear trend in entrepreneurship. The coefficient estimate on the local unemployment rate is larger (0.0074) and closer to the base specification. The quadratic, and to a lesser extent, the linear trends, might be soaking up some of the business cycle effects on entrepreneurship.
} 
All of the specifications reported in Table 1 include a dummy variable for home ownership as what could be considered a "first-order" measure of having at least some home equity to use as collateral for entrepreneurs. These regression models implicitly assume that all home owners have the same amount of equity in their homes. Although data is not available on actual home equity it is worthwhile to examine local home prices as a proxy. Home equity is determined by down payment amounts and price appreciation, but is also determined by home values. All else equal, individuals living in areas with higher home values will have more equity in their homes. An advantage of using local area home prices is that they are more exogenous to business creation at the individual level than having individual-level information on home values. Table 2 reports estimates from regressions that replace the dummy variable for home ownership with a variable measuring local home prices for home owners. Only home owners have non-zero values for home prices. Local home prices are set to zero for all non home owners. The same set of specifications is reported.

The coefficient estimate on local home values is positive and statistically significant. The coefficient implies that having a $\$ 100,000$ higher home value results in an increase in the entrepreneurship rate of 0.011 percentage points or 4 percent of the mean rate of entrepreneurship. The decline in the national median real home price from its peak of $\$ 227,600$ in summer 2005 to $\$ 170,300$ at the end of 2009 was smaller. Thus, the effect of a major change in median home prices on the entrepreneurship rate is not large. The additional specifications reported in Table 2 do not change this conclusion. The estimates reported in the remaining specifications are similar or smaller. Furthermore, I estimate a specification that includes only home owners in the sample and find a larger estimate, but the estimate also does not imply a large effect (not reported). For home owners, having $\$ 100,000$ more in home values results in an increase in the entrepreneurship rate of 0.017 percentage points. 
In sum, both of the estimated effects of housing equity, although positive, are small relative to the effects of local unemployment rates. ${ }^{14}$ Home owners are more likely to start businesses than non-home owners and home owners with higher local home prices are more likely to start businesses, all else equal, but the effects are not large. In contrast, the effects of the local unemployment rate are large and substantial. I focus more on these effects below.

Before moving to the next analysis, it is useful to briefly discuss issues of endogeneity. Although MSA-level unemployment rates and median house prices are more exogenous than individual-level measures, there remains the concern about endogeneity. For example, a positive relationship between local unemployment rates and business creation may partly capture the effects of local government policies attempting to spur job creation in high unemployment areas through encouraging business creation. The specifications with MSA fixed effects capture the effects of local government pro-business policies that are fixed over time, but not transitory policies which are very difficult to identify. Another possibility is that individuals may move to metropolitan areas with many entrepreneurial opportunities and these areas may also be the ones with the highest demand for housing. Unfortunately, the CPS does not follow households that move so it is impossible to explore this issue with these data. Although endogeneity concerns such as these may partly influence the estimates suggesting some caution in interpreting the results, the estimates are likely to be primarily driven by local labor and housing market conditions. The theory indicates the possibility of large positive causal effects of local labor market conditions and housing equity on business creation which are consistent with the results.

\section{INTERACTIONS WITH EMPLOYMENT STATUS}

The current estimates of local labor market effects capture the net effect of local economic conditions on entrepreneurship. It is possible that different groups of individuals

\footnotetext{
${ }^{14}$ Including interactions between home ownership and home equity with local unemployment rates, I find small and statistically insignificant estimates. There does not appear to be a differential business creation reaction to local labor market conditions based on home equity.
} 
respond differently to local economic conditions which could provide some suggestive evidence on the two main opposing factors influencing entrepreneurship in recessions. On the one hand, high unemployment rates could increase entrepreneurship because of limited opportunities in the labor market. We then might expect individuals who are not employed to respond positively to higher local unemployment rates. On the other hand, recessions limit demand for the products and services of entrepreneurs. In this case, individuals who currently have wage/salary jobs would be reluctant to leave those jobs to start a business that might struggle in these economic conditions. Wage/salary workers thus might respond negatively or at least less positively to higher local unemployment rates. They still might face wage cuts or hours reductions in slack labor market influencing their decision to try business ownership.

To investigate this question, I use information in the CPS on the individual's initial labor force state, measured in the initial survey month of the two-month pair. I identify whether the individual is working in a wage/salary job or not employed, and interact this information with the MSA unemployment rate. In this case, the following regression equation for the probability of entrepreneurship is estimated:

(5.2) $\mathrm{y}_{\mathrm{imt}}=\alpha+\gamma_{1}{ }^{\mathrm{W}} \mathrm{W}_{\mathrm{imt}}{ }^{*} \mathrm{U}_{\mathrm{mt}}+\gamma_{1}{ }^{\mathrm{N}} \mathrm{N}_{\mathrm{imt}} \mathrm{U}_{\mathrm{mt}}+\varphi \mathrm{N}_{\mathrm{imt}}+\gamma_{2} \mathrm{H}_{\mathrm{imt}}+\beta^{\prime} \mathrm{X}_{\mathrm{imt}}+\lambda_{\mathrm{t}}+\varepsilon_{\mathrm{imt}}$,

where $\mathrm{W}_{\mathrm{imt}}$ is whether the individual works in a wage/salary job in the initial survey month and $\mathrm{N}_{\mathrm{imt}}$ is whether the individual is not employed in the initial survey month. In this case, we are interested in the parameters, $\gamma_{1}{ }^{\mathrm{W}}$ and $\gamma_{1}{ }^{\mathrm{N}}$. These parameters capture the effects of local labor market conditions on the employed and not employed, respectively.

Table 3 reports estimates of (5.2). Starting with Specification 1, wage/salary workers do not appear to respond to local unemployment rates. The coefficient on the interaction term is small and statistically insignificant. In contrast, the coefficient on the not employed interaction with the local unemployment rate is large, positive and statistically significant. The coefficient estimate implies that individuals who are not currently employed are 0.045 percentage points 
more likely to start businesses when local unemployment rates rise by 5 percentage points. This is a relatively large effect.

The main effect of not being employed is also included in the regression. Individuals who are not currently employed are much more likely than wage/salary workers to start businesses in the following month. The coefficient estimate is large, positive and statistically significant. The unemployed and individuals not in the labor force may face different incentives for entrepreneurship, especially if they were recently laid off from their jobs. More specifically, they have a lower opportunity cost of starting a business because of the lost returns to tenure and experience on their jobs.

Additional specifications show roughly similar results. Individuals who are not employed have higher business creation rates in the face of higher unemployment rates. The results for business creation among wage/salary workers are not consistent across specifications. I find a negative coefficient in one specification and a positive and significant coefficient in one specification. In two specifications I find smaller, positive coefficients. In all of the additional specifications, I find large, positive and statistically significant coefficients on the dummy variable for not being employed. Finally, estimates do not differ substantially when including home values instead of home ownership (Table 4).

In sum, the estimates provide evidence that those initially not working respond positively to higher local unemployment rates. Wage/salary workers who might often wait for better economic conditions are not found to respond strongly to higher unemployment rates. The results are consistent with bad labor market conditions leading to higher levels of business creation out of necessity.

\section{TYPES OF BUSINESSES CREATED IN SLACK LABOR MARKETS}

What types of businesses are created in recessions? How does this compare to the types of businesses created in strong growth periods? In this section, I identify the most common types 
of businesses created in very slack labor markets and compare these to the types of businesses created in very tight labor markets. This analysis may shed additional light on recessionary effects on entrepreneurship. To conduct the analysis, I separate individuals into those residing in MSAs in the top quartile for unemployment rates and those residing in the bottom quartile for unemployment rates. The CPS provides information on the industries of the businesses created.

Table 5 reports estimates for aggregate industries. High unemployment MSAs are defined by having a local unemployment rate in the $4^{\text {th }}$ quartile, which is 6.6 percent or higher. Low unemployment MSAs are defined as having a local unemployment rate in the $1^{\text {st }}$ quartile, which is 3.7 percent or lower. Local unemployment rates vary not only across MSAs, but over time. Thus, recessionary periods contribute greatly to high local unemployment areas in this analysis. Estimates from the CPS indicate that businesses created in slack local labor market conditions represent a diverse set of industries. The largest representation of new businesses in high unemployment markets are in Professional and Business Services (20.8 percent) and Construction (20.6 percent). Education and Health Services capture 12.7 percent and Wholesale and Retail Trade capture another 12.3 percent of all new businesses. The remaining new businesses are concentrated in a wide range of industries.

Interestingly, the distribution of new businesses created in tight local labor market conditions is very similar. Professional and Business Services and Construction continue to capture the highest shares of new businesses. Education and Health Services and Wholesale and Retail Trade capture the next two highest shares. In most cases, the share of businesses created in low unemployment markets in each industry differs by less than a percentage point than the share for businesses created in high unemployment markets. The distribution of industries represented by businesses created in high unemployment markets is also similar to the total for all MSAs. These results do not indicate a few "desperation" industries for businesses created in weak labor markets. 
To further investigate industry differences by newly created businesses across economic conditions, I estimate regressions for the probability of creating a business in each of the twelve listed industries. The sample is limited to individuals creating businesses. The local unemployment rate and all of the controls listed in Specification 1 of Table 1 are included in the regressions. The coefficient on the local unemployment rate provides an estimate of whether local labor market conditions affect the probability that a business is created in a specific industry (conditional on the business being created). Table 5 reports estimates of the effects of a 1 percentage point increase in the local unemployment rate on the probability of choosing each industry. Local unemployment rates have essentially no effect on the likelihood of choosing a particular industry. All of the coefficient estimates are small in magnitude, which is consistent with the similarity of industry distributions by high and low local unemployment rates. ${ }^{15}$

Table 5 also examines whether the industry distribution of new businesses differs in the Great Recession from non-recessionary years. Similar to the results comparing high and low local unemployment rate areas, businesses created in the Great Recession do not appear to be very different than the businesses created in non-recessionary periods.

\section{HOW MUCH DOES THE BUSINESS CYCLE AFFECT ENTREPRENEURSHIP?}

How well do trends in local unemployment rates explain recent trends in entrepreneurship? To examine this question, I calculate predicted trends in entrepreneurship from 1996 to 2009 based solely on changes in local unemployment rates and compare these trends to trends in actual entrepreneurship rates. The analysis provides additional evidence on the relative magnitude of the coefficient estimates reported in Table 1. To match the sample used to estimate coefficients, I focus on the total metropolitan area entrepreneurship rate. Figure 7 displays the total MSA entrepreneurship rate from 1996 to 2009. The total MSA entrepreneurship rate follows the same trend as the national rate displayed in Figure 3. Most importantly, the increase in the

\footnotetext{
${ }^{15}$ All of the coefficient estimates are statistically insignificant.
} 
recent recession from an entrepreneurship rate of 0.29 percent in 2006 to 0.34 percent in 2009 is identical for the national and MSA samples.

Predicted entrepreneurship rates follow the same general trend as actual entrepreneurship rates (see Figure 7). The main difference is that the predicted rates do not fall as much in the strong economic growth period of the late 1990s. The predicted entrepreneurship rate remains more constant over this period. Predicted entrepreneurship rates, however, track the Great Recession very well. The predicted entrepreneurship rate increases from 0.29 percent in 2006 to 0.33 percent in 2009 , which is very similar to the actual increase in entrepreneurship rates over this period. These results indicate that the recent rise in entrepreneurship rates is primarily due to the rapidly weakening conditions in the labor market as measured by local unemployment rates.

In Figure 8, I examine how well trends in local home prices predict entrepreneurship trends. Predicted entrepreneurship rates rise from an earlier level of 0.30 percent in the late $1990 \mathrm{~s}$ to 0.31 percent at the peak of the housing market in 2006. As the housing market collapsed starting in 2007, the predicted entrepreneurship rate dropped back down to 0.30 percent. These were small changes relative to the rise in entrepreneurship rates that actually occurred from 2006 to 2009. Although not reported, I also examine trends in predicted entrepreneurship rates based on changes in home ownership rates. The pattern is even weaker for the predicted entrepreneurship rate, which is consistent with the combination of weak trends in home ownership and a relatively small coefficient from the regression analysis.

The estimates displayed in these figures makes clear the relative importance of factors determining trends in entrepreneurship, especially in the recent recession. Changes in local labor market conditions are the main determinant of changes in the entrepreneurship rate. Although over the full sample period they do not predict changes in entrepreneurship rates perfectly, they predict the recent recession almost perfectly. In contrast, changes in the housing market, either through declining levels of home ownership or declining home values, do not predict changes in 
entrepreneurship rates well. Furthermore, trends in housing markets predict declining and not rising entrepreneurship rates in the recent recession.

\section{Conclusions}

Recessions have a large negative effect on business closings and foreclosures, but what effect do they have on business creation? The net effects of lower potential levels of business income and wealth, and lower potential wage/salary earnings on entrepreneurship are theoretically ambiguous. The most up-to-date microdata available -- the 1996 to 2009 Current Population Survey (CPS) -- are used to conduct a detailed analysis of the determinants of entrepreneurship to answer this question. Regression estimates indicate that local labor market conditions are a major determinant of entrepreneurship. Higher local unemployment rates, measured at the MSA level and each month over the sample period, are found to increase the probability that individuals start businesses. The similarity of estimates from specifications including MSA fixed effects suggest that economic fluctuations over time are primarily identifying the large positive relationship between entrepreneurship and local unemployment rates. Home ownership and local home values for home owners are also found to have positive effects on business creation, but these effects are noticeably smaller.

Additional regression estimates indicate that individuals who are initially not employed are more likely to respond to higher local unemployment rates by starting businesses. The evidence is not as clear that individuals who are initially employed also respond positively to higher local unemployment rates. These findings suggest that business ownership may provide an important alternative to unemployment for many individuals facing poor labor market conditions. Several states provide self-employment assistance and lump-sum payments to unemployment insurance recipients through federally authorized Self-Employment Assistance (SEA) programs (Benus et al. 1994, Vroman 1997; Kosanovich and Fleck 2001, U.S. Department of Labor 2010). Programs providing self-employment assistance to unemployment insurance recipients also exist 
in other countries including Belgium, Canada, Finland, France, Greece, Netherlands, Portugal, Spain and the United Kingdom OECD (1992). Although these programs may encourage and assist some of the unemployed in starting successful businesses, for many others, the risky nature of entrepreneurship is not suitable. More research is needed on the long-term effectiveness of these programs, especially in terms of business performance, income generation and job creation.

Overall, the results point to a consistent picture - slack labor market conditions are a key determinant of business creation. Although the corresponding declines in home ownership and housing equity in recessionary periods work in the opposite direction by decreasing access to financial capital they are not nearly as large as the counter-cyclical effects of local labor market conditions. The positive effects of individuals turning to self-employed business ownership because of the lack of better opportunities in the wage/salary sector outweigh the negative effects of limited demand and access to capital.

The historically rapid rise in unemployment rates in the Great Recession resulted in an increase in entrepreneurship rates. Using regression estimates for the local unemployment rate effects, I find that the predicted trend in entrepreneurship rates tracks the actual trend in entrepreneurship extremely well for the Great Recession. I can predict the entire increase in entrepreneurship rates in the past few years from only the rapidly deteriorating labor market conditions. Estimates for home ownership and housing equity, on the other hand, indicate a small decline in entrepreneurship since the start of the recession. Over the longer sample period, I find that trends in entrepreneurship generally follow a counter-cyclical pattern, but these trends are much less pronounced than the counter-cyclical trends in unemployment rates. For example, the unemployment rate increased by 100 percent from 2006 to 2009, whereas the entrepreneurship rate increased by 16 percent.

Understanding the effects of recessions on business formation is important because of the contributions of entrepreneurship to job creation, innovation, and wealth in the U.S. economy (Small Business Administration 2010, OECD 2005, U.S. Whitehouse 2009, Haltiwanger, Jarmin 
and Miranda 2010). ${ }^{16}$ Although a large number of small businesses struggled and failed in the Great Recession, many new businesses that ultimately will be very successful may have been created. Recent findings by Stangler (2009) indicate that 57 percent of the current list of Fortune 500 companies was started during previous recessions or bear markets. The finding presented here that businesses created in very slack labor markets and the Great Recession have a similar industry distribution as those created in economic growth periods suggests that business formation in economic downturns are not limited to a narrow set of types of businesses. Therefore, one positive byproduct of the recent severe recession is that a wide range of eventually-successful firms might emerge and contribute to the long-run economy.

\footnotetext{
${ }^{16}$ In his inaugural address (January 20, 2009), President Obama stressed the importance of entrepreneurs for leading the country out of the recession by stating that "it has been the risk-takers, the doers, the makers of things ... who have carried us up the long, rugged path towards prosperity and freedom."
} 


\section{References}

Avery, Robert B., Raphael W. Bostic, and Katherine A. Samolyk. 1998. "The Role of Personal Wealth in Small Business Finance," Journal of Banking and Finance, 22: 1019-1061.

Bates, Timothy. 1997. Race, Self-Employment \& Upward Mobility: An Illusive American Dream, Washington, D.C.: Woodrow Wilson Center Press and Baltimore: John Hopkins University Press.

Bates, Timothy, and Magnus Lofstrom. 2008. "African Americans' Pursuit of Self-Employment," Public Policy Institute of California Working Paper.

Benus, J. M., Johnson, T. R, Wood, M., Grover, N., \& Shen, T. 1995. Self-employment programs: A new reemployment strategy: Final report on the UI Self-Employment Demonstration (Unemployment Insurance Occasional Paper 95-4). Washington, DC:

Black, Jane, David de Meza, and David Jeffreys. (1996). "House Prices, The Supply of Collateral and the Enterprise Economy." The Economic Journal. 106 (434):60-75.

Blanchflower, David G. and Oswald, Andrew J. "What Makes and Entrepreneur?" Journal of Labor Economics, 16(1), January, 1998: 26-60.

Bradford, William D. 2003. "The Wealth Dynamics of Entrepreneurship for Black and White Families in the U.S.," Review of Income and Wealth, 49(1): 89-116.

Cavalluzzo, Ken and John Wolken. 2005. "Small Business Loan Turndowns, Personal Wealth and Discrimination." Journal of Business, 78(6): 2153-2177.

Dunn, Thomas and Holtz-Eakin, Douglas. "Financial Capital, Human Capital and the Transition to Self-Employment: Evidence from Intergenerational Links." Journal of Labor Economics, 18(2), April, 2000: 282-305.

Davis, Steven J., John Haltiwanger, Ron Jarmin, C.J. Krizan, Javier Miranda, A1 Nucci and Kristen Sandusky. 2006. "Measuring the Dynamics of Young and Small Businesses: Integrating the Employer and Nonemployer Universes," CES Working Paper No. 06-04, February.

Elsby, Michael, Bart Hobijn, And Ayşegül Şahin. 2010. "The Labor Market in the Great Recession," Prepared for Brookings Panel on Economic Activity, March 18-19, 2010.

Evans, David S. and Jovanovic, Boyan. "An Estimated Model of Entrepreneurial Choice under Liquidity Constraints." Journal of Political Economy, 97(4), August, 1989: 808-827.

Evans, David S. and Leighton, Linda S. "Some Empirical Aspects of Entrepreneurship." American Economic Review, 79(3), June, 1989: 519-535.

Fairlie, Robert W. 1999. "The Absence of the African-American Owned Business: An Analysis of the Dynamics of Self-Employment." Journal of Labor Economics, 17(1): 80-108.

Fairlie, Robert W. 2010. The Kauffman Index of Entrepreneurial Activity: 1996-2009. Ewing Marion Kauffman Foundation: Kansas City. 
Fairlie, Robert W., and Alicia M. Robb. 2007. "Why are Black-Owned Businesses Less Successful than White-Owned Businesses: The Role of Families, Inheritances, and Business Human Capital," Journal of Labor Economics, 25(2): 289-323.

Fairlie, Robert W., and Alicia M. Robb. 2008. Race and Entrepreneurial Success: Black-, Asian-, and White-Owned Businesses in the United States, Cambridge: MIT Press.

Fairlie, Robert W., and Christopher Woodruff. 2010. "Mexican-American Entrepreneurship," Berkeley Electronic Journals, Contributions to Economic Analysis \& Policy.

Farber, Henry S. "Alternative and Part-Time Employment Arrangements as a Response to Job Loss.” Journal of Labor Economics, 17(4), Part 2, October, 1999: S142-S169.

Federal Housing Finance Agency. 2009. House Price Indexes. http://www.fhfa.gov/Default.aspx?Page=87

Federal Reserve System, Board of Governors. 2010. "The January 2010 Senior Loan Officer Opinion Survey on Bank Lending Practices,"

http://www.federalreserve.gov/boarddocs/snloansurvey/201002/fullreport.pdf

Giannetti, M. and Simonov, A.. 2004. "On the determinants of entrepreneurial activity: Social norms, economic environment and individual characteristics," Swedish Economic Policy Review 11(2), 271.313.

Haltiwanger, John C., Ron S. Jarmin, and Javier Miranda. 2010. "Who Creates Jobs? Small vs. Large vs. Young,” NBER Working Paper No. 16300.

Headd, Brian. 2005. "Business Estimates from the Office of Advocacy: A Discussion of Methodology," U.S. Small Business Administration, Office of Advocacy Working Paper

Holtz-Eakin, Douglas, David Joulfaian and Harvey S. Rosen. 1994. "Entrepreneurial Decisions and Liquidity Constraints.” RAND Journal of Economics, 25(2), Summer: 334-347.

Holtz-Eakin, Douglas, and Harvey S. Rosen (2005): "Cash Constraints and Business Start-Ups: Deutschmarks versus Dollars," Berkeley Electronic Journals, Contributions to Economic Analysis \& Policy: Vol. 4: No. 1, Article 1.

Johansson, Edvard. "Self-Employment and Liquidity Constraints: Evidence from Finland." Scandinavian Journal of Economics, 102(1), March, 2000: 123-134.

Kosanovich, William T., Heather Fleck, Berwood Yost, Wendy Armon, and Sandra Siliezar. 2001. Comprehensive Assessment of Self-Employment Assistance Programs, U.S. Department of Labor Report.

Krashinsky, Harry A. "Self-Employment for Less-Educated Men.” Mimeo, University of Toronto, 2005.

Lindh, Thomas, and Henry Ohlsson. 1996. "Self-Employment and Windfall Gains: Evidence from the Swedish Lottery.” Economic Journal, 106(439), November: 1515-1526. 
Lindh, Thomas, and Henry Ohlsson. 1998, "Self-employment and wealth inequality," Review of Income and Wealth, 44(1), 25.41.

Lofstrom, Magnus, and Chunbei Wang. 2009. "Hispanic Self-Employment: A Dynamic Analysis of Business Ownership," Research in Labor Economics, 29: 197-227.

Meyer, Bruce 1990. "Why Are There So Few Black Entrepreneurs?," National Bureau of Economic Research, Working Paper No. 3537.

Moutray, Chad. 2007. "Educational Attainment and Other Characteristics of the Self-Employed: An Examination using the Panel Study of Income Dynamics Data," U.S. Small Business Administration Working Paper.

Nykvist, Jenny. 2005. "Entrepreneurship and Liquidity Constraints: Evidence from Sweden," Uppsala University, Department of Economics, Working Paper 2005:21.

National Bureau of Economic Research. 2010. Business Cycle Expansions and Contractions, http://www.nber.org/cycles.html, (accessed June 2 2010).

OECD. 1992. Employment Outlook 1992, Paris: OECD. http://www.oecd.org/dataoecd/4/8/2409984.pdf

OECD. 2005. SME and Entrepreneurship Outlook - 2005 Edition, Organisation for Economic Co-operation and Development Press.

Parker, Simon C. (2009). The Economics of Entrepreneurship. Cambridge: Cambridge University Press.

PricewaterhouseCoopers $(\mathrm{PwC})$ and the National Venture Capital

Association (NVCA). 2010. MoneyTree ${ }^{\mathrm{TM}}$ Report, based on data provided by Thomson Reuters. www.pwcmoneytree.com

Realtytrac. 2010. " National Real Estate Trends," http://www.realtytrac.com/trendcenter/

Reynolds, Paul D., William D. Bygrave, and Erkko Autio. 2003. Global Entrepreneurship Monitor: 2003 Executive Report. Babson College, London Business School and the Kauffman Foundation.

Stangler, Dane. 2009. The Economic Future just Happened, Kansas City: Ewing Marion Kauffman Foundation, http://www.kauffman.org/uploadedFiles/the-economic-future-justhappened.pdf

Stangler, Dane, and Paul Kedrosky. 2010. "Exploring Firm Formation: Why is the Number of New Firms Constant?," Kauffman Foundation Research Series: Firm Formation and Economic Growth, Kansas City: Kauffman Foundation.

Taylor, Mark P. "Self-Employment and Windfall Gains in Britain: Evidence from Panel Data." Economica, 68(272), November, 2001: 539-565.

U.S. Bureau of Labor Statistics. 2010. Employment Situation. http://www.bls.gov/news.release/empsit.toc.htm 
U.S. Census Bureau. 2008. Home Ownership Statistics.

U.S. Courts. 2010. Bankruptcy Statistics.

http://www.uscourts.gov/Statistics/BankruptcyStatistics.aspx

U.S. Department of Labor, Employment and Training Administration, Unemployment Insurance Service.

U.S. Department of Labor. 2010. Self-Employment Assistance, http://www.workforcesecurity.doleta.gov/unemploy/self.asp

U.S. Small Business Administration. 2010.

http://www.sba.gov/idc/groups/public/documents/sba_homepage/serv_aboutsba_perf_summ.pdf).

U.S. Small Business Administration, Office of Advocacy. 2001. "Private Firms, Establishments, Employment, Annual Payroll and Receipts by Firm Size, 1998-2001" Table reported at http://www.sba.gov/advo/stats/us_tot.pdf.

van der Sluis, J., van Praag, M., and Vijverberg, W. 2005. "Education and Entrepreneurship in Industrialized Countries: A Meta-Analysis," World Bank Economic Review, 19(2): 225-261.

van Praag, Mirjam. 2005. Successful Entrepreneurship: Confronting Economic Theory with Empirical Evidence, London: Edward Elgar.

Vroman, Wayne. 1997. "Self-Employment Assistance: Revised Report." Urban Institute: Washington, D.C.

Zissimopoulos, Julie, and Lynn Karoly. 2003. "Transitions to Self-Employment at Older Ages," RAND Working Paper. 
Figure 1: National Unemployment Rate

U.S. Bureau of Labor Statistics (1996-2009)

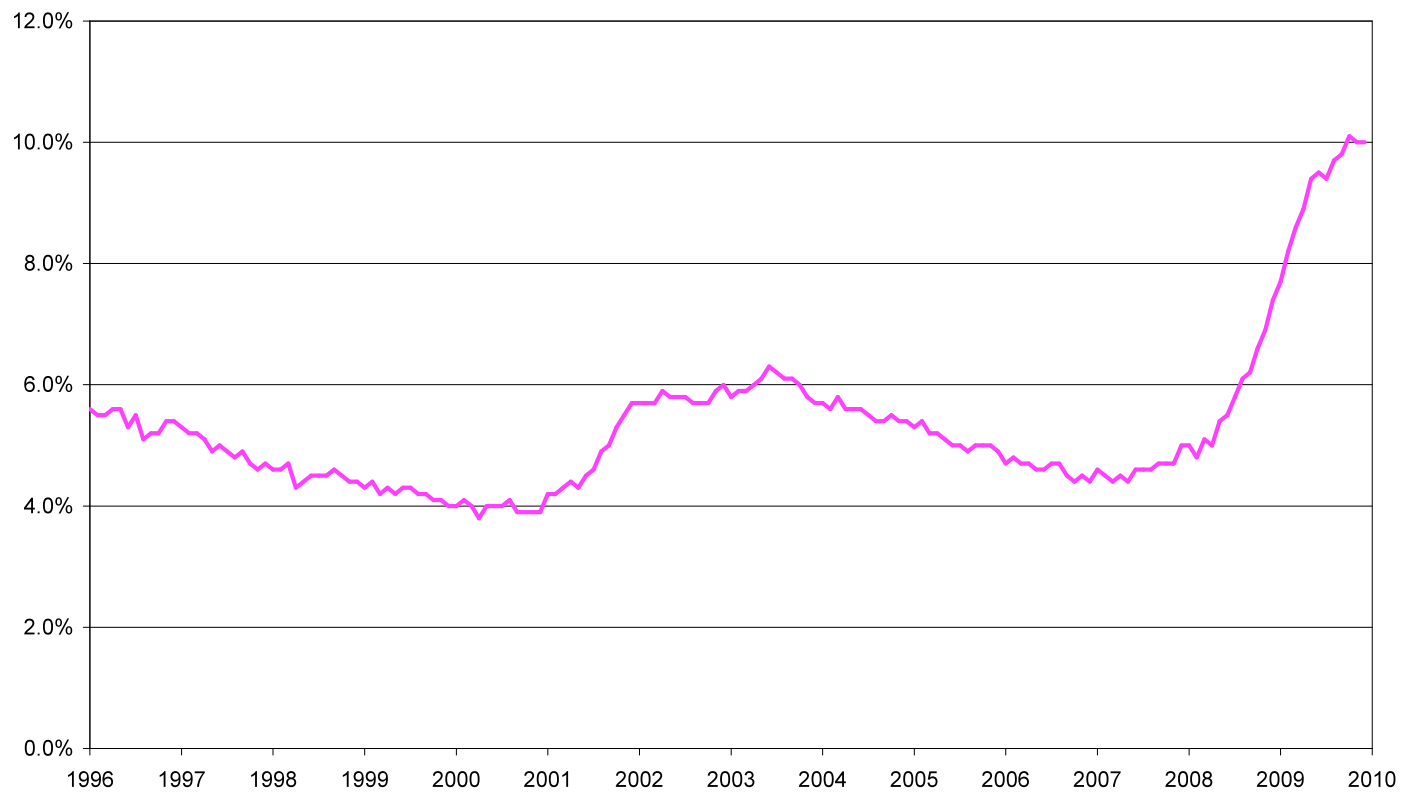


Figure 2: Median Sales Price of Existing Single-Family Homes and Home Ownership Rates National Association of Realtors (1996-2009) and Current Population Survey (1996-2009)

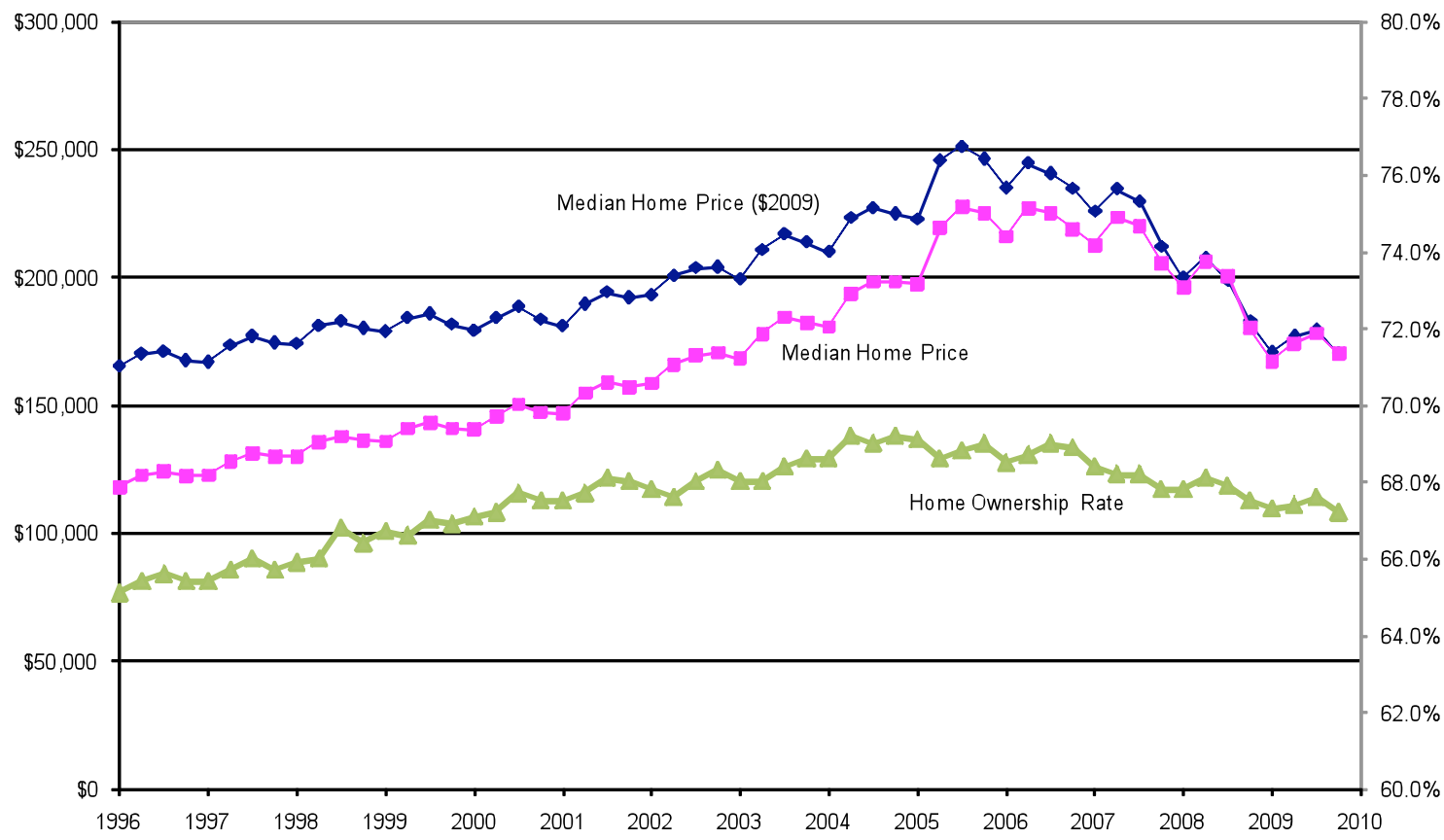


Figure 3: Entrepreneurship and Unemployment Rates

Current Population Survey and U.S. Bureau of Labor Statistics (1996-2009)

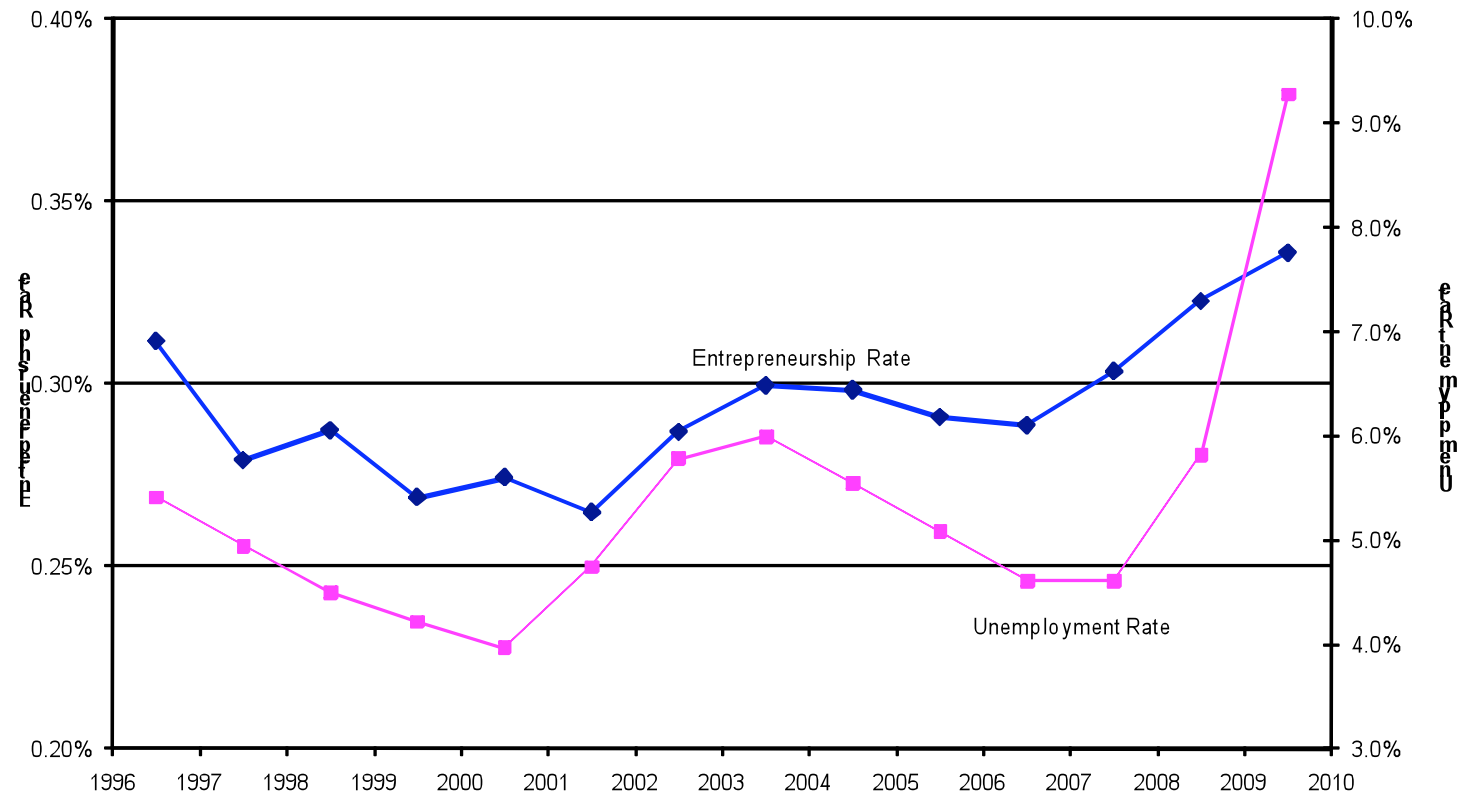


Figure 4: Entrepreneurship Rates and Median Home Prices

Current Population Survey and National Association of Realtors (1996-2009)

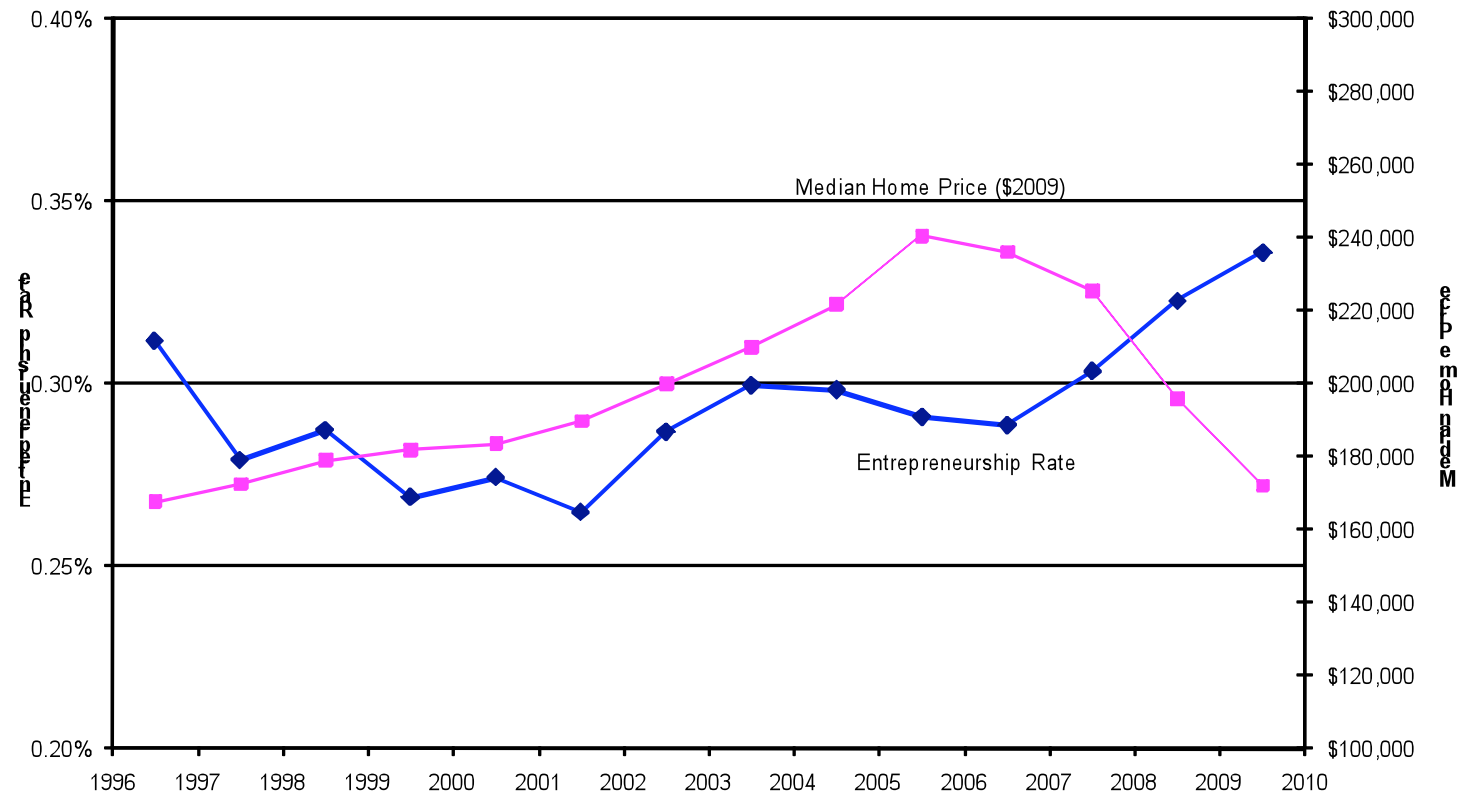


Figure 5: Entrepreneurship Rates by Local Unemployment Rates Current Population Survey (1996-2009)

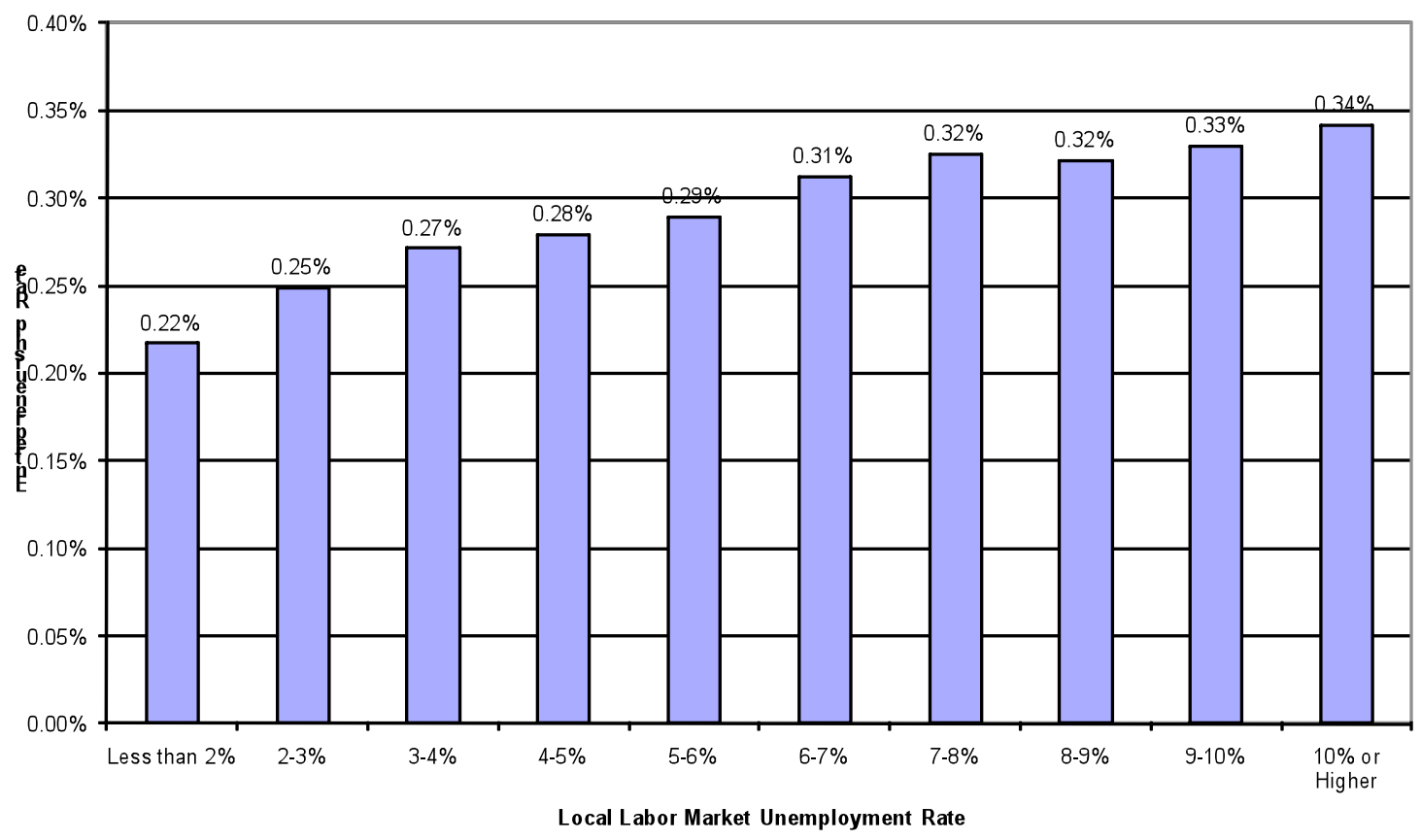


Figure 6: Entrepreneurship Rates by MSA Median Home Prices Current Population Survey (1996-2009)

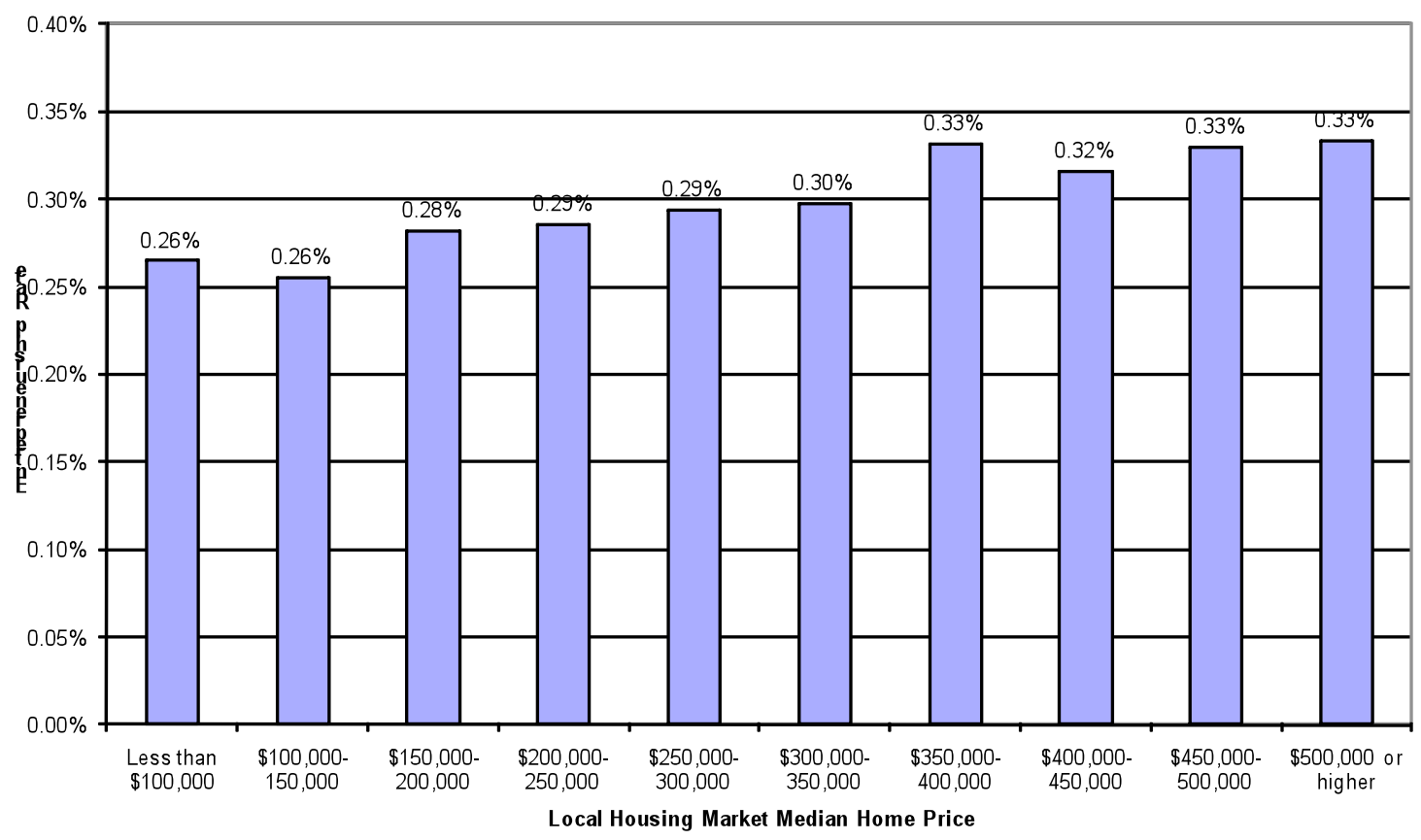


Figure 7: Actual and Predicted MSA Entrepreneurship Rates from Local Unemployment Trends

Current Population Survey (1996-2009)

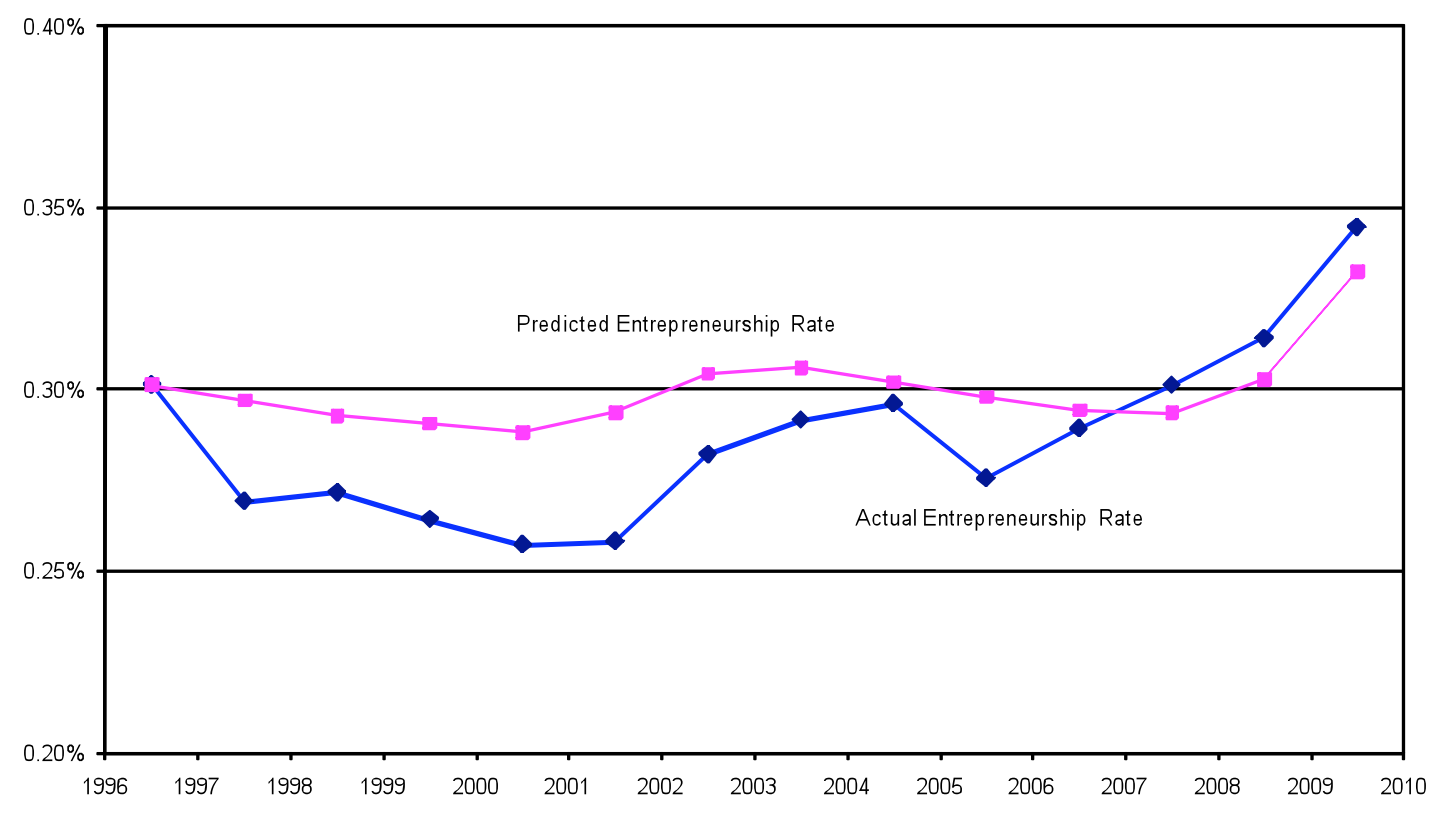


Figure 8: Actual and Predicted MSA Entrepreneurship Rates from Local Home Value Trends Current Population Survey (1996-2009)

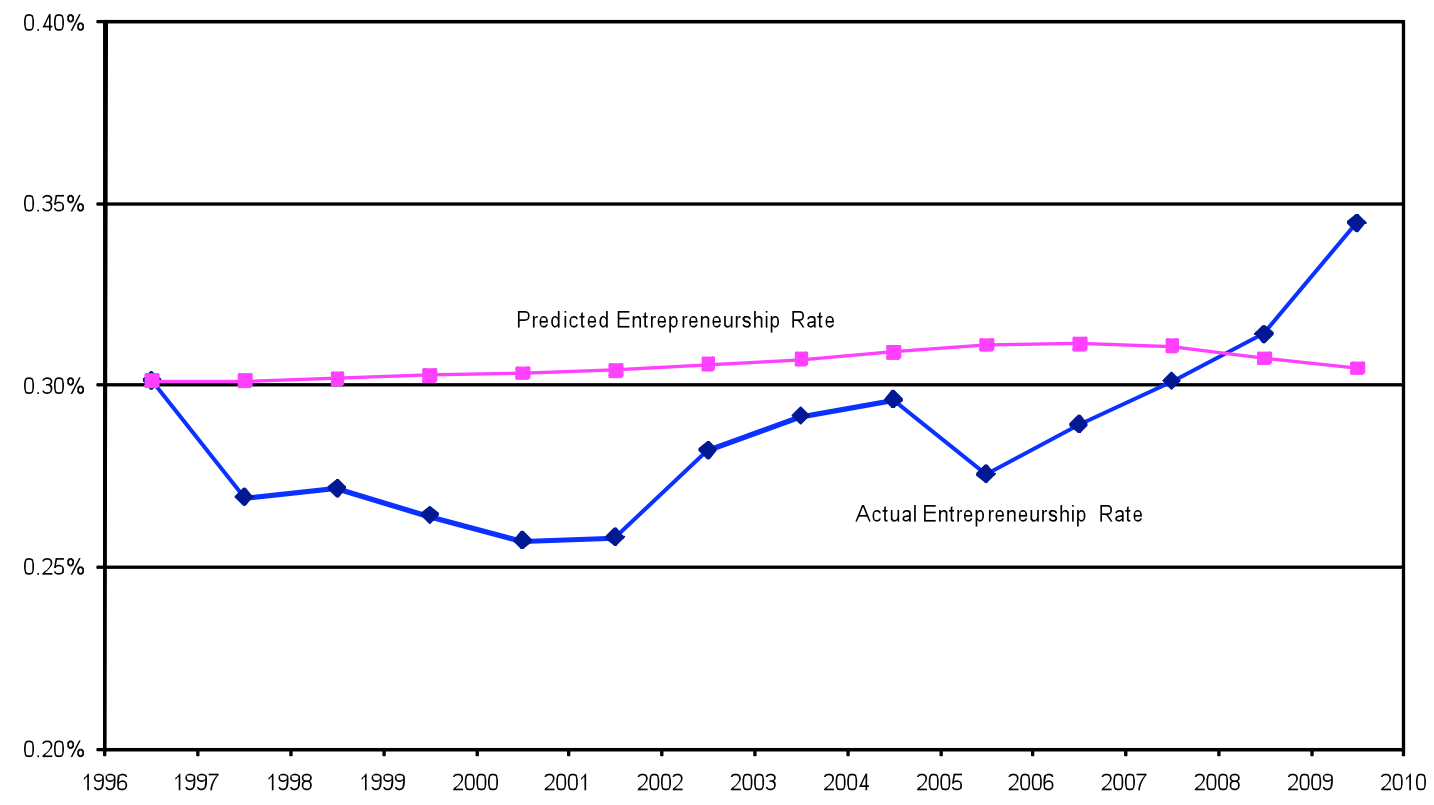


Table 1

Regressions for Probability of Entrepreneurship

Current Population Survey (1996-2009)

\begin{tabular}{|c|c|c|c|c|}
\hline Explanatory Variables & (1) & (2) & (3) & (4) \\
\hline Female & $\begin{array}{l}-0.00136 \\
(0.00005)\end{array}$ & $\begin{array}{l}-0.00165 \\
(0.00006)\end{array}$ & $\begin{array}{l}-0.00136 \\
(0.00005)\end{array}$ & $\begin{array}{l}-0.00137 \\
(0.00005)\end{array}$ \\
\hline Black & $\begin{array}{l}-0.00089 \\
(0.00008)\end{array}$ & $\begin{array}{l}-0.00074 \\
(0.00008)\end{array}$ & $\begin{array}{l}-0.00089 \\
(0.00008)\end{array}$ & $\begin{array}{l}-0.00100 \\
(0.00008)\end{array}$ \\
\hline Latino & $\begin{array}{l}-0.00056 \\
(0.00010)\end{array}$ & $\begin{array}{l}-0.00043 \\
(0.00010)\end{array}$ & $\begin{array}{l}-0.00058 \\
(0.00010)\end{array}$ & $\begin{array}{l}-0.00076 \\
(0.00011)\end{array}$ \\
\hline Native American & $\begin{array}{l}-0.00013 \\
(0.00036)\end{array}$ & $\begin{array}{l}-0.00019 \\
(0.00036)\end{array}$ & $\begin{array}{l}-0.00013 \\
(0.00036)\end{array}$ & $\begin{array}{l}-0.00018 \\
(0.00036)\end{array}$ \\
\hline Asian & $\begin{array}{l}-0.00127 \\
(0.00014)\end{array}$ & $\begin{array}{l}-0.00127 \\
(0.00014)\end{array}$ & $\begin{array}{l}-0.00127 \\
(0.00014)\end{array}$ & $\begin{array}{l}-0.00126 \\
(0.00015)\end{array}$ \\
\hline Immigrant & $\begin{array}{c}0.00117 \\
(0.00010)\end{array}$ & $\begin{array}{c}0.00109 \\
(0.00010)\end{array}$ & $\begin{array}{c}0.00116 \\
(0.00010)\end{array}$ & $\begin{array}{c}0.00096 \\
(0.00010)\end{array}$ \\
\hline Age (00s) & $\begin{array}{c}0.01686 \\
(0.00153)\end{array}$ & $\begin{array}{c}0.03214 \\
(0.00160)\end{array}$ & $\begin{array}{c}0.01709 \\
(0.00154)\end{array}$ & $\begin{array}{c}0.01672 \\
(0.00154)\end{array}$ \\
\hline Age squared & $\begin{array}{l}-0.01767 \\
(0.00182)\end{array}$ & $\begin{array}{l}-0.03771 \\
(0.00191)\end{array}$ & $\begin{array}{l}-0.01805 \\
(0.00182)\end{array}$ & $\begin{array}{l}-0.01765 \\
(0.00183)\end{array}$ \\
\hline Married & $\begin{array}{l}0.00056 \\
(0.00007)\end{array}$ & $\begin{array}{c}0.00043 \\
(0.00007)\end{array}$ & $\begin{array}{c}0.00058 \\
(0.00007)\end{array}$ & $\begin{array}{c}0.00062 \\
(0.00007)\end{array}$ \\
\hline Previously married & $\begin{array}{c}0.00022 \\
(0.00009)\end{array}$ & $\begin{array}{c}0.00035 \\
(0.00009)\end{array}$ & $\begin{array}{c}0.00024 \\
(0.00009)\end{array}$ & $\begin{array}{c}0.00026 \\
(0.00009)\end{array}$ \\
\hline High School graduate & $\begin{array}{l}-0.00036 \\
(0.00010)\end{array}$ & $\begin{array}{c}0.00018 \\
(0.00010)\end{array}$ & $\begin{array}{l}-0.00037 \\
(0.00010)\end{array}$ & $\begin{array}{l}-0.00040 \\
(0.00010)\end{array}$ \\
\hline Some college & $\begin{array}{l}-0.00029 \\
(0.00010)\end{array}$ & $\begin{array}{c}0.00040 \\
(0.00010)\end{array}$ & $\begin{array}{l}-0.00030 \\
(0.00010)\end{array}$ & $\begin{array}{l}-0.00035 \\
(0.00010)\end{array}$ \\
\hline College graduate & $\begin{array}{l}-0.00001 \\
(0.00011)\end{array}$ & $\begin{array}{c}0.00085 \\
(0.00012)\end{array}$ & $\begin{array}{l}-0.00002 \\
(0.00011)\end{array}$ & $\begin{array}{l}-0.00012 \\
(0.00011)\end{array}$ \\
\hline Graduate school & $\begin{array}{l}-0.00006 \\
(0.00013)\end{array}$ & $\begin{array}{c}0.00105 \\
(0.00013)\end{array}$ & $\begin{array}{l}-0.00007 \\
(0.00013)\end{array}$ & $\begin{array}{l}-0.00016 \\
(0.00013)\end{array}$ \\
\hline Family income: missing & $\begin{array}{l}-0.00023 \\
(0.00011)\end{array}$ & $\begin{array}{l}-0.00001 \\
(0.00011)\end{array}$ & $\begin{array}{l}-0.00028 \\
(0.00011)\end{array}$ & $\begin{array}{l}-0.00030 \\
(0.00011)\end{array}$ \\
\hline $\begin{array}{l}\text { Family income: } \$ 25,000 \text { to } \\
\qquad \$ 50,000\end{array}$ & $\begin{array}{l}-0.00120 \\
(0.00009)\end{array}$ & $\begin{array}{l}-0.00059 \\
(0.00009)\end{array}$ & $\begin{array}{l}-0.00122 \\
(0.00009)\end{array}$ & $\begin{array}{l}-0.00124 \\
(0.00009)\end{array}$ \\
\hline $\begin{array}{l}\text { Family income: } \$ 50,000 \text { to } \\
\qquad \$ 75,000\end{array}$ & $\begin{array}{l}-0.00184 \\
(0.00010)\end{array}$ & $\begin{array}{l}-0.00106 \\
(0.00010)\end{array}$ & $\begin{array}{l}-0.00187 \\
(0.00010)\end{array}$ & $\begin{array}{l}-0.00192 \\
(0.00010)\end{array}$ \\
\hline $\begin{array}{l}\text { Family income: } \$ 75,000 \text { or } \\
\text { more }\end{array}$ & $\begin{array}{l}-0.00171 \\
(0.00010)\end{array}$ & $\begin{array}{l}-0.00098 \\
(0.00010)\end{array}$ & $\begin{array}{l}-0.00178 \\
(0.00010)\end{array}$ & $\begin{array}{l}-0.00188 \\
(0.00010)\end{array}$ \\
\hline
\end{tabular}


Table 1 (Continued)

\begin{tabular}{|c|c|c|c|c|}
\hline Explanatory Variables & (1) & (2) & (3) & (4) \\
\hline Local Unemployment Rate & $\begin{array}{c}0.00841 \\
(0.00106)\end{array}$ & $\begin{array}{c}0.00807 \\
(0.00106)\end{array}$ & $\begin{array}{c}0.00674 \\
(0.00109)\end{array}$ & $\begin{array}{c}0.01153 \\
(0.00112)\end{array}$ \\
\hline Home owner & $\begin{array}{c}0.00012 \\
(0.00007)\end{array}$ & $\begin{array}{c}0.00008 \\
(0.00007)\end{array}$ & $\begin{array}{c}0.00013 \\
(0.00007)\end{array}$ & $\begin{array}{c}0.00020 \\
(0.00007)\end{array}$ \\
\hline Industry controls & No & Yes & No & No \\
\hline Entrepreneurship trend & No & No & Yes & No \\
\hline MSA fixed effects & No & No & No & Yes \\
\hline Mean of dependent variable & 0.00287 & 0.00287 & 0.00287 & 0.00287 \\
\hline Sample size & $5,694,980$ & $5,694,980$ & $5,694,980$ & $5,694,980$ \\
\hline
\end{tabular}


Table 2

Regressions for Probability of Entrepreneurship with Home Values

Current Population Survey (1996-2009)

\begin{tabular}{lcccc} 
Explanatory Variables & $(1)$ & $(2)$ & $(3)$ & $(4)$ \\
\hline Local unemployment rate & 0.00942 & 0.00888 & 0.00756 & 0.01175 \\
& $(0.00126)$ & $(0.00126)$ & $(0.00130)$ & $(0.00132)$ \\
Local home value for home & 0.00011 & 0.00008 & 0.00010 & 0.00005 \\
owners $(\$ 100,000)$ & $(0.00002)$ & $(0.00002)$ & $(0.00002)$ & $(0.00002)$ \\
Industry controls & No & Yes & No & No \\
Entrepreneurship trend & No & No & Yes & No \\
MSA fixed effects & No & No & No & Yes \\
Mean of dependent variable & 0.00290 & 0.00290 & 0.00290 & 0.00290 \\
Sample size & $4,976,595$ & $4,976,595$ & $4,976,595$ & $4,976,595$ \\
\hline
\end{tabular}

Notes: (1) The sample consists of individuals (ages 20-64) who do not own a business in the initial survey month of the two-month pair. (2) Local home values are set to zero for all non-home owners. (3) Additional controls include month, region and urban status 
Table 3

Regressions for Probability of Entrepreneurship with Labor Force Interactions Current Population Survey (1996-2009)

\begin{tabular}{lcccc} 
Explanatory Variables & $(1)$ & $(2)$ & $(3)$ & $(4)$ \\
\hline Employed*local & 0.00121 & 0.00131 & -0.00015 & 0.00467 \\
unemployment rate & $(0.00083)$ & $(0.00083)$ & $(0.00086)$ & $(0.00092)$ \\
Not employed*local & 0.00903 & 0.00411 & 0.00772 & 0.01261 \\
unemployment rate & $(0.00286)$ & $(0.00284)$ & $(0.00286)$ & $(0.00287)$ \\
Not employed & 0.00606 & 0.00871 & 0.00605 & 0.00605 \\
& $(0.00018)$ & $(0.00021)$ & $(0.00018)$ & $(0.00018)$ \\
Home owner & -0.00002 & 0.00007 & -0.00001 & 0.00006 \\
& $(0.00007)$ & $(0.00007)$ & $(0.00007)$ & $(0.00007)$ \\
Industry controls & No & Yes & No & No \\
Entrepreneurship trend & No & No & Yes & No \\
MSA fixed effects & No & No & No & Yes \\
Mean of dependent variable & 0.00287 & 0.00287 & 0.00287 & 0.00287 \\
Sample size & $5,694,980$ & $5,694,980$ & $5,694,980$ & $5,694,980$ \\
\hline Notes: (1) The sample consists of individuals (ages 20-64) who do not own a business in \\
the initial survey month of the two-month pair. (2) Additional controls include month, region \\
and urban status dummies.
\end{tabular}


Table 4

Regressions for Probability of Entrepreneurship with Labor Force Interactions Current Population Survey (1996-2009)

\begin{tabular}{lcccc} 
Explanatory Variables & $(1)$ & $(2)$ & $(3)$ & $(4)$ \\
\hline Employed*local & 0.00256 & 0.00255 & 0.00102 & 0.00536 \\
unemployment rate & $(0.00104)$ & $(0.00103)$ & $(0.00108)$ & $(0.00112)$ \\
Not employed*local & 0.00708 & 0.00160 & 0.00558 & 0.01017 \\
unemployment rate & $(0.00329)$ & $(0.00327)$ & $(0.00330)$ & $(0.00332)$ \\
Not employed & 0.00622 & 0.00898 & 0.00622 & 0.00621 \\
& $(0.00021)$ & $(0.00024)$ & $(0.00021)$ & $(0.00021)$ \\
Local home value for home & 0.00006 & 0.00006 & 0.00006 & 0.00001 \\
owners (\$100,000) & $(0.00002)$ & $(0.00002)$ & $(0.00002)$ & $(0.00002)$ \\
Industry controls & No & Yes & No & No \\
Entrepreneurship trend & No & No & Yes & No \\
MSA fixed effects & No & No & No & Yes \\
Mean of dependent variable & 0.00290 & 0.00290 & 0.00290 & 0.00290 \\
Sample size & $4,976,595$ & $4,976,595$ & $4,976,595$ & $4,976,595$ \\
\hline Notes: (1) The sample consists of individuals (ages 20-64) who do not own a business in \\
the initial survey month of the two-month pair. (2) Local home values are set to zero for all \\
non-home owners. (3) Additional controls include month, region and urban status
\end{tabular}


Table 5

Industry Distribution for Businesses Created by MSA Unemployment Rates Current Population Survey (1996-2009)

\begin{tabular}{|c|c|c|c|c|c|c|}
\hline Industry & $\begin{array}{c}\text { High Unemp. } \\
\text { MSAs }\end{array}$ & $\begin{array}{c}\text { Low Unemp. } \\
\text { MSAs }\end{array}$ & All MSAs & $\begin{array}{l}\text { Effect of } 1 \% \\
\text { Increase in } \\
\text { Unemp. Rate }\end{array}$ & $\begin{array}{c}\text { Great } \\
\text { Recession }\end{array}$ & $\begin{array}{c}\text { Non- } \\
\text { Recession } \\
\text { Months } \\
\end{array}$ \\
\hline Agriculture & $3.6 \%$ & $3.9 \%$ & $3.3 \%$ & $0.1 \%$ & $2.4 \%$ & $3.3 \%$ \\
\hline Construction & $20.6 \%$ & $18.4 \%$ & $19.3 \%$ & $0.1 \%$ & $17.0 \%$ & $18.7 \%$ \\
\hline Manufacturing & $3.3 \%$ & $2.9 \%$ & $3.2 \%$ & $0.0 \%$ & $4.5 \%$ & $3.1 \%$ \\
\hline Wholesale/Retail Trade & $12.3 \%$ & $10.8 \%$ & $12.0 \%$ & $0.1 \%$ & $11.5 \%$ & $12.2 \%$ \\
\hline Trans/Utilities & $3.8 \%$ & $3.2 \%$ & $3.5 \%$ & $0.0 \%$ & $3.7 \%$ & $3.6 \%$ \\
\hline Information & $2.7 \%$ & $2.3 \%$ & $2.7 \%$ & $0.0 \%$ & $3.6 \%$ & $2.8 \%$ \\
\hline Financial Activities & $6.2 \%$ & $6.9 \%$ & $6.7 \%$ & $0.0 \%$ & $8.9 \%$ & $6.6 \%$ \\
\hline Professional/Business Services & $20.8 \%$ & $23.4 \%$ & $22.2 \%$ & $-0.2 \%$ & $27.7 \%$ & $22.0 \%$ \\
\hline Education/Health Services & $12.7 \%$ & $14.9 \%$ & $13.5 \%$ & $-0.2 \%$ & $11.8 \%$ & $13.8 \%$ \\
\hline Leisure/Hospitality & $6.5 \%$ & $5.8 \%$ & $6.3 \%$ & $0.1 \%$ & $3.1 \%$ & $6.4 \%$ \\
\hline Other Services & $7.5 \%$ & $7.6 \%$ & $7.4 \%$ & $-0.1 \%$ & $6.1 \%$ & $7.6 \%$ \\
\hline Sample size & 4,270 & 3,760 & 16,223 & 15,944 & 2,106 & 13,338 \\
\hline
\end{tabular}

Notes: (1) The sample consists of individuals (ages 20-64) who start a business in the second survey month of the two-month pair. (2) High unemployment MSAs are defined by having unemployment rates in the 4th quartile (6.6 percent and higher), and low unemployment MSAs are defined by having unemployment rates in the 1st quartile (3.7 percent and less). (3) The effect of a 1 percentage point increase in the unemployment rate is estimated from a regression for the probability of being in that industry on the local unemployment rate and the controls included in Specification 1 of Table 1. 